\title{
Influences of Egyptian Lotus Symbolism and Ritualistic Practices on Sacral Tree Worship in the Fertile Crescent from 1500 BCE to 200 CE
}

\section{J. Andrew McDonald}

Department of Biology, The University of Texas-Rio Grande Valley, 1201 W. University Dr., Edinburg, TX 78539, USA; andrew.mcdonald@utrgv.edu

Received: 2 August 2018; Accepted: 23 August 2018; Published: 27 August 2018

\begin{abstract}
Many conventional features of world tree motifs in the ancient Near East-including stalked palmettes, aureoles of water lily palmettes connected by pliant stems, floral rosettes, winged disks and bud-and-blossom motifs-trace largely from Egyptian practices in lotus symbolism around $2500 \mathrm{BCE}$, more than a millennium before they appear, migrate and dominate plant symbolism across the Fertile Crescent from 1500 BCE to 200 CE. Several of these motifs were associated singularly or collectively with the Egyptian sema-taui and ankh signs to symbolize the eternal recurrence and everlasting lives of Nilotic lotus deities and deceased pharaohs. The widespread use of lotus imagery in iconographic records on both sides of the Red Sea indicates strong currents of cultural diffusion between Nilotic and Mesopotamian civilizations, as does the use of lotus flowers in religious rituals and the practice of kingship, evidence for which is supported by iconographic, cuneiform and biblical records. This perspective provides new insights into sacral tree symbolism and its role in mythic legacies of Egypt and the Middle East before and during the advent of Christianity. Closer scholarly scrutiny is still needed to fully comprehend the underlying meaning of immortalizing plants in the mythic traditions of Egypt, the Levant and Mesopotamia.
\end{abstract}

Keywords: Nilotic lotus; sacral tree; ankh; sema-taui; Bible; kingship; libation ritual

\section{Introduction}

As both a symbol and iconographic prop, sacral tree images on palace and temple reliefs, murals, seals, jewelry and ritualistic implements of the Middle East continue to "provoke more discussion and controversy than almost any other element in Mesopotamian art" (Black et al. 1992, p. 170). Portrayals and historical uses of these motifs remain an enigma to most historians and evoke little agreement with respect to their botanical identity and allegorical significance (Atac 2008; Giovino 2007, pp. 21-30). While most recent commentators identify visual impressions of the motif as a date palm (Albenda 1994; Black et al. 1992, pp. 46, 170-71; Mazar 1961, vol. 4, p. 71; Moldenke and Moldenke 1952, p. 191; Parpola 1993; Porter 1993), this utilitarian plant was in fact a frequent feature in depictions of mundane scenes of palace life and agricultural panoramas. The date palm is occasionally associated with various gods and goddesses, sacrificial rituals and libation scenes in artistic media, but primarily among specimens from the 3rd and 2nd millenia BCE and Achaemedian cylinder seals from the 6-5th c. BCE (Danthine 1937, pls. 3-9, 16). In such examples, the plant exhibits clearly interpretable features of a date palm: i.e., stout, singular trunks with persistent leaf bases, pinnate fronds, several pendent and woody, spathate flowering stalks and date fruits.

On other occasions, historians have also identified a variety of stylized images of a Mesopotamian sacral tree and its exuberant flowers with cedars, firs, oaks, pomegranates, roses, willows or members of the sunflower family (Bonavia 1894, pp. 3-7, 44-45, 58; Danthine 1937; James 1966, pp. 13, 42, 75, 98, 
106, 162; Moldenke and Moldenke 1952, pp. 191, 286). These wide-ranging interpretations notwithstanding, a more recent botanical assessment of the issue challenges most of the aforementioned determinations (McDonald 2002), noting that most sacral trees that post-date 1500 BC lack the aforementioned characteristics of a date palm, while manifesting many vegetative and fertile characteristics that are categorically inconsistent with palm tree morphology, such as pliant stems, an aureole of interconnected palmettes with blue-pigmented appendages, the latter often surrounding a golden disk, fruits with prominent calyx segments and close associations with a cone-like object. From a botanical viewpoint, these and other characteristics of the plant suggest a species that once dominated marshes of the Nile, Tigris and Euphrates River systems: the Nilotic lotus (Nymphaea nouchali Burm. f.). Blue-pigmented palmettes of these sacred trees appear to represent lateral perspectives of water lily corolla, while trunk-like features signify a stout and succulent water lily stalk. Although this perspective is by no means original (Coomaraswamy 1935; Danthine 1937; Goodyear 1887, 1891; Jones [1856] 1995, pp. 22-23, 28-29), modern historians have inexplicably ignored this interpretation during most of the 20th century.

The use of lotus symbolism throughout the Fertile Crescent and Egypt during the second and first millennia BCE is one of many practices that reveals a long history of cultural contacts between early civilizations of the Nile River and Fertile Crescent. While many of Egypt's earliest written records make direct reference to Middle Eastern peoples (Redford 1992, pp. 19-24, 33), the widespread usage of Egyptian symbols (ankhs, djeds, uraei, lotus flowers, etc.), apparel (robes, sandals, crowns, and staffs) and presentation of zoomorphic gods and chimeras of Egyptian origin (falcons, scarabs, jackals, etc.) throughout the Levant and Mesopotamia during the Middle Bronze Age (2000-1700 BCE; (Keel and Uehlinger 1998, p. 25, Figures 8a,b, 15c, 32c and 34c)), with a secondary peak of popularity during the Middle Iron Age (ca. 1000 BCE; (Keel and Uehlinger 1998, pp. 210-81)), attest to significant and enduring influences of Egyptian culture over peoples throughout the Fertile Crescent. It is well known that Levantine communities in ancient Egypt exercised considerable influence over the Nile delta from the 19-16th centuries BCE (i.e., the Hyksos; (Shaw and Nicholson 1995, p. 136; Keel and Uehlinger 1998, p. 17)), during which period various Canaanite gods and goddesses, such as Qadesh (Qetesh), Anat (Anthat), Ashtoreth (Astarte) and Baal (Bar), joined the ranks of the Egyptian pantheon (Budge [1904] 1969, vol. 2, pp. 278-81; Shaw and Nicholson 1995, pp. 32, 42, 237; Redford 1992, pp. 231-33). Pre- and post-exilic biblical records of Judah reveal in no uncertain terms that Hebrew-speaking tribes of Canaan and their neighbors embraced various pantheons and religious practices of both Egypt and Mesopotamia (Lang 1983, pp. 18-26, 41; Patai 1990; Keel and Uehlinger 1998, pp. 2-3); hence iconographic forms and conventions of ancient Egypt, the Levant, and Mesopotamia intermingle freely with one another in archaeological sites that date from the second and first millennia BCE (Jones [1856] 1995, pp. 23-29; Merhav 1987; Frankfort 1970; Black et al. 1992, p. 84; Cline 1995).

Differing schools of iconology and mythology have yet to reconcile whether or not shared symbolic elements and mythological themes of distant civilizations in Egypt, the Middle East and Europe have arisen coincidentally (independently) or by means of cultural diffusion. While either or both of these explanations might apply to any particular motif, it is incumbent upon historians to argue their specific perspectives on an individual basis and support their views by drawing equally from evidence in archaeological and written records. Ideally, their interpretations should be compatible with ritualistic and religious customs of each historical age. In the present study, botanical considerations on the use of lotus symbolism in Egypt and the Near East focus primarily on iconographic evidence, and then tests hypothetical interpretations of floral and vegetative imagery by matching their visually contextual and mythical presentations with historical and scriptural records.

In the case of lotus symbolism, we are well-informed of the plant's prominent role in Egyptian mythology by a wealth of scriptural and artistic evidence from the distant past. This is not, however, the case for lotus symbolism in the Fertile Crescent, which has yet to be explored and examined comprehensively under these unique geographical and cultural circumstances. This incongruency owes in no small part to the dominant role of linguistic fields of inquiry in the study of Mesopotamian and Near Eastern history, whose ongoing contributions are often at 
a loss to identify ancient plant names and highly stylized vegetative and floral motifs on a botanical basis (Darby et al. 1977, pp. 36-37; Giovino 2007, pp. 12-16; Moldenke and Moldenke 1952, pp. 2-9). Furthermore, it has long been assumed by art historians that sacral tree imagery relates to the cultivation, pollination, and sanctification of date palms (Black et al. 1992, p. 46), direct botanical confirmation of which has been challenged in many cases by McDonald (2002) and others (Giovino 2007, pp. 77-90; Goodyear 1887, 1891). Since the physical and behavioral attributes of date palms have limited relevance to standard mythical features of the Fertile Crescent's sacred trees, such as aquatic origins, solar attributes or contacts, and close associations with divine serpents and eagles (McDonald 2002), various authorities have concluded that literary references in cuneiform and biblical sources have no direct bearing on sacral tree imagery in the visual arts (James; (Black et al. 1992, p. 171; Parpola 1993)). This perspective seems to be at variance, however, with iconographic records in palaces and temples, which afford ample visual and textual evidence of such a plant, many referring explicitly to an aquatic, resplendent, flowering plant of the immortal gods. References to this plant are encountered frequently in mythic records of the Sumerians, Akkadians, and Canaanites (Pritchard 1969), and often in association with mythical creatures that agree with visual portrayals of sacral trees in archaeological records. They simply defy the logic of suggestions that this ubiquitous and focal symbol of kingship and religious ritual in Akkadia, Assyria, Babylonia and the Levant fails to appear in 3000 years of mythical cuneiform records (Cooper 2000; Parpola 1993, 1997).

If the development of sacral tree symbolism in the Fertile Crescent springs from, converges upon, or parallels the development of sacred lotus symbolism in Egypt (Coomaraswamy 1935; Goodyear 1887, 1891; Jones [1856] 1995, pp. 22-23, 28-29; McDonald 2002), then it only follows that the mythic and symbolic significance of Mesopotamian and Near Eastern sacral trees should share both iconographic and mythic relations with the Nile's ubiquitous water lily motifs. McDonald (2002) explored this subject briefly, primarily by relating mythical attributes of the sacral tree to physical and behavioral characteristics of the Nilotic lotus. But that inquiry hardly scratches the surface of a very complex subject and therefore invites closer examination of the origin and historical developments of sacred tree symbolism in the Middle East. To accomplish this goal, it is useful to consider from the outset the mythic and religious significance of lotus symbolism on the banks of the Nile River.

This investigation approaches a popular and familiar topic from a unique perspective, insofar as the fundamental premises for interpretations of the ubiquitous Nilotic lotus of Egypt and the Middle East are based primarily on the author's botanical background and observations on the distinctive morphic and behavioral characteristics: a plant species that subordinates all other symbolic plants in terms of frequency of use. The diurnal, blue Nilotic lotus, Nymphaea nouchali Burm. f. (s.l.), is a member of the aquatic water lily family, and exhibits a natural distribution that ranges across tropical latitudes of Africa and Asia. A related species of this same plant group is also known materially from archeological records and occasionally in iconographic records of Egypt and the Middle East-the nocturnal, white-flowered night lotus, Nymphaea lotus L.-but this species plays a relatively minor role in symbolism and religious ritual. The large and blue, resplendent, sun-like flowers of the day-bloomer seem to have captivated the imaginations of Egyptian and Mesopotamian peoples like no other for at least three millennia, and accordingly dominated the use of plant symbolism in mythic and religious traditions of distant human communities. Biological insights provide novel and somewhat heterodoxic viewpoints on ancient iconographic records and, in so doing, highlight details in symbolic expression that are rarely considered while also contesting a number of popular viewpoints of modern historians.

\section{The Egyptian Lotus as a Symbol of Immortal Life}

Lotus symbolism is a hallmark of religious expression in pharaonic Egypt and permeates most temple complexes and mortuary sites of pre-Christian origin. Some of Egypt's earliest written records make direct reference to the plant, many appearing in early mortuary chambers of Old Kingdom dynasts at Saqqara, particularly those of King Unas (ca. 2375-2345 BCE). A compilation of these hieroglyphic records with English translations in "The Ancient Egyptian Pyramid Texts" (Faulkner 1969) is replete 
with mythical references to the first living being to emerge from the life-giving waters of ancient Egypt, this being the Nilotic blue lotus. Arising in the sky from a mythical islet of the Nile known as On, not far from the historical city of Heliopolis (modern Cairo) as a solar cum water lily god of creation known as Atum or Nefer-Atum (=Nefertum, or "Beauty Come-to-be"; Figure 1a), this primordial demiurge instigates living creation by breathing his flower's sweet-smelling essence across the face of the earth and shedding his creative seed into the Egyptian sky. Nefertum accomplishes these acts in three symbolically equivalent forms: (1) a water lily shoot (Figure 1a), (2) an aquatic phallus whose life-engendering ejaculum fills the earth and heavens with its procreative "spittle" (Figure 1b), or (3) a scarab beetle (Khepri) with blue-pigmented wings that lifts Egypt's immortal, golden sun-disk (Ra) on a lapis lazuli boat into the heavens (Figure 1c,d). On a symbolic level, the primeval phallus apparently symbolizes an emergent, budding water lily shaft with a swollen apical bud (Figure 2e), while the blue-winged scarab with green calyptras and a golden disk represents a full-blown, blue water lily (i.e., with green calyx, blue corolla and yellow ovarian disk, Figure 2d; (McDonald 2002)).

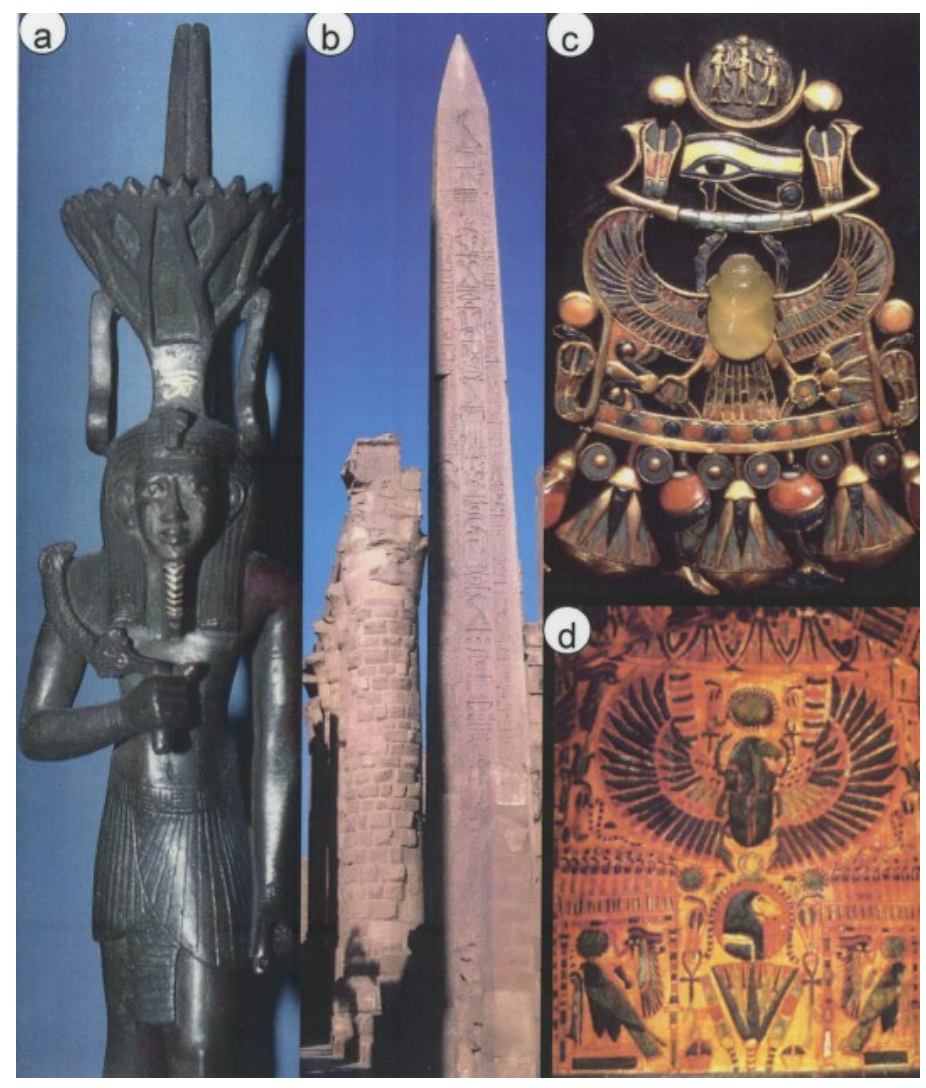

Figure 1. The cosmogenic Nilotic lotus. (a) Although Nefertum leads the Heliopolitan pantheon during the Old Kingdom, personified images of the lotus god occur commonly during the New Kingdom and Ptolemaic periods. Egypt, ca. 3rd c. BCE (Metropolitan Museum). (b) The Egyptian obelisk, a phallic symbol of Osiris-Ra, frequently bears at its apex the avian image of his solar offspring, Horus. Here, the pillar surpasses in height the massive papyrus columns of Karnak. Egypt, Karnak, 15th c. BCE. (c) Khepri lifts the lapis lazuli boat of Horus's solar eye out of a lotus grove. The divine scarab, a mythic image of the lotus-god, Nefertum, also carries two symbols of immortal life within his talons: shen loops and a cluster of two lotus buds and blossom. Thebes, Valley of the Kings, Tomb of Tutankhamen, 14th c. BCE (Cairo Museum). (d) A ram-headed scarab beetle with blue wings emerges from a lotus blossom to push forth the flower's golden disk. A pair of cobras (uraei) dangle from the solar-floral disk, each upholding an ankh. The latter symbols complement the flanking pair of lotus buds to either side of the blossom, as well as paired avian images of Horus (blue falcons) yet to take flight. Egypt, coffin of Pameshen, ca. 10th c. BCE (Cairo Museum). 


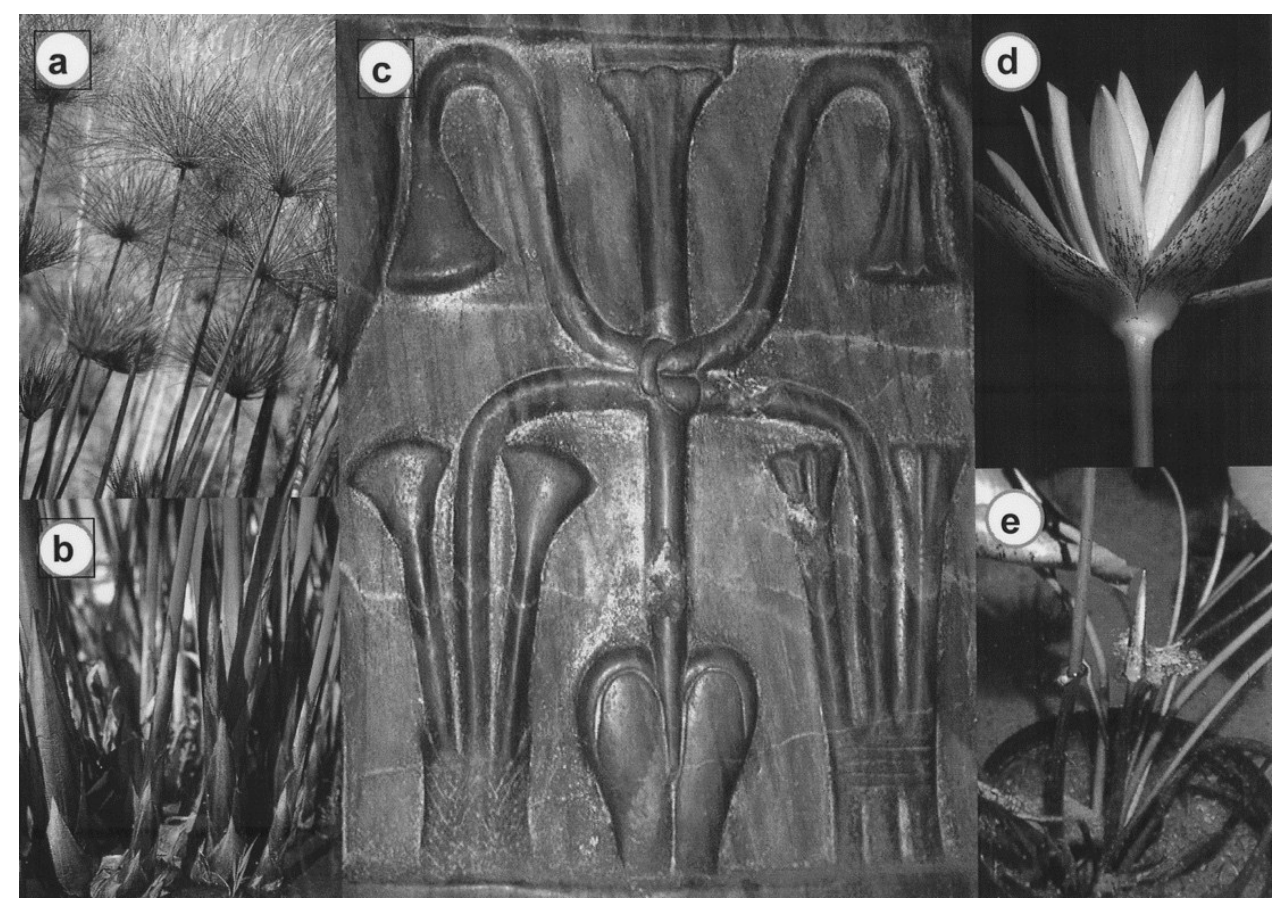

Figure 2. The "Union" Symbol (sema-taui) of ancient Egypt. (a) Fertile stalks of the papyrus plant present a cluster of chaffy bracts and a spray of slender shoots. Details of these complex structures are often simplified as a campanulate motif in the visual arts (Figure 2c). (b) Papyrus stems are supported at their base by long, chaffy bracts. (c) Early renderings of the sema-taui symbol portray a central lotus stalk that is supported by knotted lotus and papyrus stems. Note that the central stalk arises from a testicular base and supports a three-membered palmette (lotus flower) at its apex. Throne of Chephren, Giza, 26th c. BCE (Cairo Museum). (d) The profile view of a polypetalous Egyptian water lily exhibits three prominent green sepals and a palmate array of blue-pigmented petals. (e) Lotus stalks lack the distinctive basal bracts of a papyrus shoot. Note that a new bud has arisen before a flower stalk has finished its three days of anthesis.

The Heliopolitan perspective on natural creation does not culminate with the cosmogenic activities of a divine flower, but proceeds to describe the subsequent creation of four successive generations of gods and goddesses, the last of which includes two brothers and sisters-namely Osiris, Seth, Isis, and Nephthys-whose conflictive interactions on the banks of the Nile immortalize the natural world's life cycles by establishing the everlasting processes of procreation and death. Nefertum's fourth-generation descendants experience a daily drama of fratricide and necromancy, whereby Seth, the envious brother of the sun god, Osiris-Ra, submerges and drowns his sibling's phallus on the banks of the Nile River at the end of each day (Table 1, 1. 1), thereby compelling his divine sisters, Isis and Nephthys, to seek out and guard the virile member of their fallen, solar brother (Table 1, l. 2). 
Table 1. Citations from Egyptian Heiroglyphic Inscriptions. PT = Pyramid Texts (Faulkner 1969); CT = Coffin Texts (Faulkner 2004); BD = Book of the Dead (Budge [1899] 1989).

\begin{tabular}{|c|c|}
\hline 1 & PT $24,615,972,1256,1500$ \\
\hline 2 & PT 616, 1255-56, 2144 \\
\hline 3 & PT 581-82, 632-633, 1636, 2018-2019 \\
\hline 4 & PT 766, 1068, 1799-800 \\
\hline 5 & PT 167-92, 1298, 2098, 2146 \\
\hline 6 & BD 264, 594 \\
\hline 7 & PT $198,238,976,1056,1146-48$ \\
\hline 8 & СТ $316,351,388-89,455,462$ \\
\hline 9 & BD 315-16 \\
\hline 10 & PT 513-14, 776, 1833-37 \\
\hline 11 & PT 1624-26, 1824 \\
\hline 12 & PT 788-92 \\
\hline 13 & PT 788-92; PT 1180; PT 1227, respectively \\
\hline 14 & PT 275, 1247, 1421, 1430 \\
\hline 15 & PT 1345-46 \\
\hline 16 & PT 145, 152, 156, 1686; CT 350, 169, 352 \\
\hline 17 & СТ 188 \\
\hline 18 & PT 1164-67 \\
\hline 19 & PT $770,961,994,1475$ \\
\hline 20 & PT 632, 956-59, 1061 \\
\hline 21 & PT 1460-63 \\
\hline 22 & PT 535 \\
\hline 23 & PT 946-47 \\
\hline 24 & PT 792, 1066, 1781 \\
\hline 25 & PT 770 \\
\hline 26 & PT 513-14 \\
\hline 27 & PT 60-61, 264-66 \\
\hline 28 & PT 391 \\
\hline 29 & CT 335; 2: 292-300 \\
\hline 30 & PT 1962-67; CT 223; BD XLII. 10-14, LXXI. 3-8 \\
\hline 31 & BD XLII \\
\hline 32 & PT 22-23, 43, 47, 73, 114, 1682, 1800-802, 2071-73; CT 607; BD CX, CXVI \\
\hline 33 & PT 1801, 2071-2073 \\
\hline 34 & PT 1959 \\
\hline 35 & PT 1643, 1754, 1802, 2073, 2075, CT 530, 840, 861; PT 1241; PT 332, 1902-903, respectively \\
\hline 36 & BD CX, CXVI \\
\hline 37 & СТ 167 \\
\hline
\end{tabular}

Isis, a fertility goddess, eventually couples with the fallen phallus, conceiving by Osiris her one and only son, Horus, who emerges from the Nile River at the dawning of each day in the image of a golden-crowned, blue-winged falcon (Table 1, 1. 3; Figure 4c). Horus, who is often described as the eye of the sun, returns the seed of his father to its original source-an aquatic phallus in the aquatic underworld of the Nile (Table 1, 1. 4) -and in so doing revitalizes his own biological/paternal source. In effect, the interactive roles of Horus and Osiris recapitulate the primordial acts of Nefertum's virile member on a daily basis (Table $1,1.5$ ) by resurrecting a cosmic phallus at the dawning of each day so as 
to conceive a solar-bodied offspring (Horus) in the form of a blue lotus: or symbolically, a blue-feathered falcon that supports a golden solar disk on his head (i.e., cradled by his blue, outstretched wings).

Egyptians and members of the Heliopolitan pantheon recognized the sun and its animate equivalent, the sun-like blossoms of the Nilotic lotus, as earthly and heavenly aspects of the Nile's first recorded Creator figure, Nefertum. Hence, the lotus flower was deemed as much a creator of life as an incarnate aspect of the everlasting sun itself. The Pyramid Texts are full of refrains that describe the lotus plant as the progenitor (i.e., as Nefertum) of the sun (Ra): not vice versa, as would be our intuitive and modern biological perspective. And judging from historical accounts of the first-century Greek historian, Plutarch, citizens of Greece were equally familiar with this traditional Nilotic perspective on the natural world just prior to the Greco-Roman Periods of Egyptian history (332 BCE-395 CE). In "Moralia: De Iside et Osiride" (V.355.11; (Babbitt 1936, p. 29)), Plutarch acknowledges that Nilotic communities symbolized the sun's aquatic origins by the image of a solar orb arising from a full-blown lotus blossom.

This mythic image endured for thousands of years and appears as though it were transcribed directly from the early dynastic tomb of Unas onto the walls of the famous Denderah temple complex during Egypt's Greco-Roman period:

The sun which exists since the beginning rises like a falcon out of the center of the lotus blossom. When the doors of the petals open in the shine of sapphire, so He (the sun god, Horus) has separated the night from the day. You are rising like the holy serpent as a living spirit! Creating, you rise and shine in your magnificent body in the boat of the rising sun. The divine master, whose image is kept hidden in the temple of Denderah, is becoming the creator of the world by his work. Coming as the One, he multiplies by millions when the light comes out of him in the form of a child. (translation of (Brugsch 1884, p. 103))

Here the lotus flower is mythically identified with the sun, a divine serpent, blue raptor, and solar barge, all of which motifs echo earlier Heliopolitan themes and ostensibly reflect the solar aspect of water lily blossoms: the serpentoid nature of water lily peduncles, the feathery features of the plant's large petals, and the flower's tendency to float on water like a blue-petalled, sun-like boat (McDonald 2002).

The use of lotus imagery to symbolize eternal life was a standard practice in pharaonic Egypt and successive dynasts were recurrently identified specifically as reincarnations of Horus during their reigns as pharaohs and incarnate spirits of Nefertum, Osiris, and the Nilotic lotus in the afterlife. It was widely believed that upon the death of a pharaoh, each sovereign was bound to arise as a lotus flower "at the nose of Ra" within the paradisal "Fields of Peace" on the Nile (="Fields of Offerings," "Underworld" or "Hidden Place" in the Book of the Dead, Table 1, 1. 6; (Budge [1925] 1989, p. 319; Budge [1904] 1969, vol. 1, p. 170)). This optimistic expectation was often represented in the visual arts by the image of an aristocrat, priest or deity upholding a lotus bloom before his or her nose (Lange and Hirmer 1968, Figures 74 and 83, pl. XXIII; El-Mallakh and Bianchi 1980, p. 112; Keel and Uehlinger 1998, Figures 32c and 107), as though the sweet-smelling essence of the Nilotic lotus was a source of his or her eternal life. The same general idea is communicated among the early inscriptions of King Unas at Saqqara, which equate the pharaoh with deified lotus shoots, solar orbs and serpent gods, as noted in the aforementioned translation of Brugsch from Denderah as well as numerous Pyramid Texts (Table 1, 1. 7) and funerary papyri known to modern Egyptologists as the Coffin Texts (Table 1, 1. 8). Needless to say, Egyptian allusions to an immortalizing plant that bears close relations to the sun and a divine serpent foreshadow mythic themes that relate to various Middle Eastern cuneiform texts and Biblical references to the tree of life (McDonald 2002; Pritchard 1969).

\section{The Ankh, Sema-Taui and Lotus Plant}

Given the aforementioned mythic roles of the Egyptian lotus, it is not surprising that the plant is often associated with Egyptian hieroglyphs and symbols that relate to eternal life. Foremost among these is the ankh insignia (Figure $3 a-c$ ), an enduring motif that eventually served Coptic churches 
in post-dynastic Egypt as the symbol of the Christian tree of life and sacrificial cross (i.e., the crux ansata; see discussion below and Figure 7; (Lurker 1980, p. 27); Table 1, 1. 9) before it disappears from historical records a few centuries after Egypt's adoption of Christianity. The ankh is one of the older and more ubiquitous symbols of ancient Egypt and one that apparently symbolized the lotus flower when it was held to the nose of gods and pharaohs (Figure 7b; (Lange and Hirmer 1968, pl. LI; Schäfer 1974, Figure 20; El-Mallakh and Bianchi 1980, p. 44; Wilkinson 1992, p. 177)). While various anthropomorphic, zoomorphic and chimeric gods and goddesses present the ankh to Osiris and Horus as a means to affect their sanctification, resuscitation, and resurrection (i.e., eternal occurrence), the sign is also employed as a symbol of the Nile's 'waters of life,' usually by portraying a cascading stream of ankh emblems from libation vases (Gillispie and Dewachter 1987, 1: pls. 10.2, 2, 11.A, 13.1; Wilkinson 1994, pp. 159-60) or by fashioning libation vases in the image of an ankh insignia (Schäfer 1974, Figure 30). In either case, the ankh sign symbolized the vitalizing breath and creative seed (i.e., 'waters' or 'efflux') of the sacred phallus and/or solar eye of various Egyptian lotus-gods, whether Nefertum-Ra, Osiris-Ra or Horus-Ra.
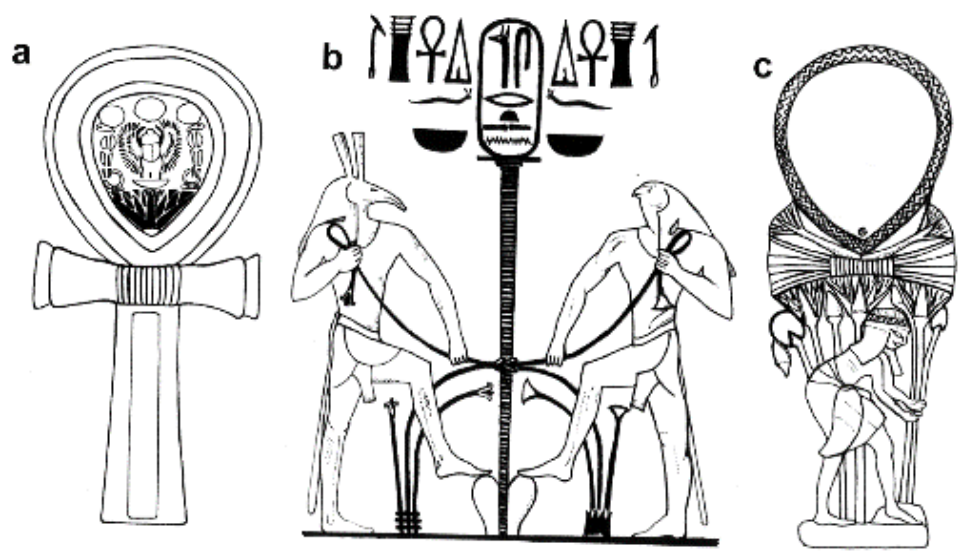

Figure 3. Ankh and lotus. (a) Mirrors and mirror cases from Egyptian tombs are often fashioned in the image of an ankh symbol and a flowering lotus stalk. Note that the stalked shen loop (an ankh) contains a lotus blossom and three golden floral disks. The triad of disks presumably symbolizes the natural three-day life span of a lotus flower. Thebes, Valley of the Kings, Tomb of Tutankhamen, 14th c. BCE (Cairo Museum). (b) Horus and Seth grasp a lotus and papyrus stalk and sustain the immortal phallus of Osiris-Ra. The phallic symbol takes the form of an ankh symbol and contains a hieroglyphic reference to Seti I. Abydos, 13th c. BCE (Cairo Museum). (c) Unguent spoons were often fashioned in the image of an ankh, stalked shen loop, and flowering lotus stalk. Note that the extended arms of the shen loop terminate in lotus blossoms and that a lotus bud and blossom motif-a symbol of immortal life-extends across the spoon. Thebes, Egypt, 13th c. BCE (Louvre Museum).

The origin of the ankh symbol has been debated for more than a century, but with little agreement as to how the symbol was derived. Most dictionaries and encyclopedic works refer to a popular hypothesis of the famous Egyptologist, Alan Gardiner (Gardiner 1928, vol. 8, pp. 19-25; 1950), who envisaged the ankh as a sandal strap. Little support for this proposition can be found, however, in epigraphic and iconographic records, as noted by Gardiner himself. While Budge (Budge [1925] 1989, pp. 315-16) and Chevalier and Gheerbrant (1996, p. 27) speculate that the loop of the ankh sign likely symbolizes the solar eye of the sun-god Ra emerging from an eastern horizon, and others attempt to derive the distinctive emblem from the image of a cow vertebra (Gordon and Schwabe 2004, pp. 102-6) or a penis sheath (Baines 1975), Egyptologists have yet to reach a consensus on the matter.

The ankh symbol is, in fact, a rather simple motif, and one that shares both direct and indirect associations with the Nilotic lotus. Numerous mirrors, mirror cases and 'unguent spoons' discovered in various reaches of the Nile River superimpose a flowering lotus stalk upon the ankh emblem (Figure 3a,c; (Maspero 1913, pp. 190-91; Baines 1975; Wilkinson 1994, p. 161, Figure 127)), identifying 
the shaft of the emblem with a lotus stalk and the terminal loop with opposing arms (a shen symbol, see below) with a lotus bud or blossom.

In a similar manner, the ankh sign is often associated with the sema-taui hieroglyph (Figures $3 \mathrm{~b}$, $4 \mathrm{a}, \mathrm{b}$ and 7c), or 'union' symbol (zm3-t3wj = 'union of the two lands'; (Wilkinson 1994, p. 90; 2003, p. 107)). This motif portrays opposing bouquets of three lotus and papyrus stalks that uphold a centralized, upright, flowering lotus stalk (Figure 2c). The term sema-taui (zm3 sm'w t3-mhjw, 'Uniter of the Upper and Lower Egypt') is derived from a royal epithet that traces its origin to the Second Dynasty (Budge [1904] 1969, vol. 2, p. 44) around 2800 BCE and connotes kingship over lands that lie between the mouth and headwaters of the Nile River system. The concept is encountered repeatedly in the Pyramid Texts, where numerous entries celebrate a deceased king's assumption of dominion over lands that lie between Nile delta and the cataracts at Philae (i.e., Upper and Lower Egypt), the natural domains of Osiris (Table 1, 1. 10) and Horus (Table 1, 1. 11). We also encounter this phrase in association with descriptions of the eternal recurrence of Osiris-Ra (an incarnation of Nefertum's floral phallus) in the aquatic 'Fields' of the sun-god, Ra.

The Nilotic 'Fields of Ra' are described mystically in the Pyramid Texts as an aquatic domain where deceased Kings reincarnate themselves as the underworld phallic sun-god, Osiris-Ra, and return to life upon flooded "serpent mounds" (Table 1, 1. 12). The sun-god's aquatic fields are identified in later inscriptions of The Great Litany of Re (Piankoff 1964) as a locality where the King assumes a vegetative aspect in the afterlife: "in the horizon and the Yaro Fields" (Piankoff 1964, pls. 20-21), like Ra himself, who, "resting on his bank" (Piankoff 1964, pl. 3: 5) and "shining in the flood," is manifest as "bodies (pl.) of the Watery Abyss." Or otherwise, the mythic sun, as the eyes (pl.) of Horus (Piankoff 1964, pls. 4: 19-24) and "brilliant bodies (pl.) of the Flaming one from the Netherworld" (Piankoff 1964, pls. 5: 40-42), arises in large numbers on a daily basis. These mythic images call to mind a plurality of golden eyes in an aquatic habitat (i.e., lotus blossoms) rather than a solar orb, for solar disks arise solitarily on dry and stark, eastern terrestrial horizons of Egypt rather than flooded riverbanks.

The Nilotic Fields of Ra are mythically equivalent to Ra's "Fields of Khepri", "Field of Life", and "Field of Strife" (i.e., between Seth and Osiris; Table 1, 1. 13), and are just as commonly identified as a Field of Reeds, Field of Felicity, Field of Peace, Field of Offerings, Field of Fire, the Tuat ('Underworld') or Amentet ('Hidden Place'; (Budge [1904] 1969, vol. 1, pp. 170-72)), all of which are conventionally described in terms of, or depicted in images as lotus groves among floating papyrus masses. Thus, Egypt's floral sun-gods are said to bathe in the Lake or Field of Rushes (Table 1, 1. 14) and to moor their celestial boats among the Field of Rushes on the "Banks of the Lower Skies" (Table 1, 1. 15; (Budge [1904] 1969, vol. 2, p. 120)). Given that the identity of Ra is repeatedly conflated with various lotus-gods known as Nefertum (as Ra-Atum and Nefetum-Ra; Table 1, 1. 16), Horus-Ra and Osiris-Ra, and is said to bathe within lotus tanks (Table 1, 1. 17), much as deceased Kings in the Field of Rushes on waterways, "like Ra on the banks of the Sky" (Table 1, 1. 18), it seems apparent that the sun-god, Ra, in his life-giving 'Fields of Peace,' embodies a dual, cosmic identity that unites the mythic and theological roles of sun-like water lilies with the Egyptian sun.

A classic pictorial representation of the sema-taui symbol is observed on the throne of Sesostris I (1291-1278 BCE), where two central figures in Heliopolitan mythology, Seth and Horus (the nemesis vs. heroic offspring of Osiris, respectively), uphold an upright ankh emblem (=shen loop, symbol of eternal life, subtended by a shaft) by pulling knotted shoots of an Egyptian lotus and papyrus stalk (Figure 3b; (Lange and Hirmer 1968, Figure 88)). This image clearly represents the mythic interactions of Horus and Seth on the Heliopolitan 'mounds' of the Field of Rushes (Table 1, 1. 19) who perpetually drown and then resurrect the phallus of Osiris-Ra.

Modern art historians usually interpret the central pillar and bi-lobed mound of this motif (Wilkinson 2003, p. 107) as a lung and windpipe (Gardiner 1950, p. 465; Lurker 1980, p. 125; Wilkinson 1992, p. 81), presumably because the central shaft often exhibits a series of horizontal ringlets. But this interpretation is unconvincing, as Egyptian mythology never associates Horus, Seth, or Osiris with a trachea or lungs. Rather, the focal ankh insignia seems to represent a phallic 
symbol that supports a terminal cartouche bearing the name of the king: the co-essence of Osiris-Ra or Nefertum-Ra in the Nilotic underworld. Arising from a testicular motif, the ankh appears to embody the phallus of either Nefertum- or Osiris-Ra, as we note its support is governed by the dual efforts of Seth and Horus. The imagery apparently relates to mythic themes in the Pyramid Texts that speak of the daily drowning of Osiris' solar phallus (Table 1, 1. 20), the daily loss of Horus' solar eye and dismemberment of Seth's testicles (Table 1, 1. 21), followed by the subsequent retrieval of Horus's solar eye, Seth's testicles (Table 1, 1. 22), and the rejuvenation of Osiris's solar eye and testicles (Table 1, 1. 23), all of which themes relate symbolically to the central ankh or lotus motif (Figures $2 c$ and $3 b$ ).

Some of the earliest depictions of the sema-taui during the 5th and 6th Dynasties originally portrayed the central motif as a flowering lotus stalk instead of an interchangeable ankh sign, while the upright stalk sometimes exhibits the same distinctive ringlets that are observed on the ankh shaft of Sesostris I (Figure 3b, compare also Figures 1d and 4a; (Budge [1904] 1969, vol. 2, p. 131)). One of the earliest-known portrayals of the sema-taui symbol appears on the famous marbled throne of an early Old Kingdom pharaoh, Chephren (2558-2532 BCE), which exhibits side panels that emphasize the same testicular element (Figure 2c). By convention, the centralized lotus stalk is supported on one side by a papyrus stem whose campanulate stalks exhibit distinctive lanceolate leaf bracts at their bases (Figure $2 b, c$ ), and by a collection of three flowering lotus stalks on the opposite side whose stems are bundled basally by three or four horizontal bars (Figure 2c-e). The central, phalliform shaft of the motif-the axis mundi of Egyptian kingship in the aspect of a flowering lotus stalk—supports the enthroned, living image of Chephren. It is equally noteworthy that the sema-taui motif was employed in the construction of dynastic thrones in a similar manner throughout Egyptian history, ostensibly identifying the central lotus stalk as a phallic axis mundi to represent Egyptian dynasts and kingship.

As regards the symbolic significance of the motif, it is remarkable that the papyrus plant never occurs in the central position of this configuration, as this role is assumed exclusively by a lotus flower, an ankh symbol, or a realistic and/or symbolic image of a king (Gillispie and Dewachter 1987, vol. 1, pls. 45.2, vol. 4, pl. 12), frequently as a cartouche bearing the hieroglyphic inscription of a pharaoh's name (Gillispie and Dewachter 1987, vol. 2, pls. 21.2, 22). Hence, the king was represented iconographically as both an axis mundi and flourishing lotus stalk. Concomitantly, the combination of lotus and papyrus elements symbolizes the blissful Fields of Ra in the upper and lower floodplains of the Nile (Table 1, 1. 24).

Since Chephren presided over Heliopolis (On), much as King Unas two centuries later, it is not surprising that the symbolic relationship between the sema-taui symbol and lotus flower on the king's throne relates to verses regarding the interactions of Seth and Horus upon the Nile's 'serpent mounds.' Early inscriptions at Saqqara identify the king's throne as a prominent feature of Nefertum's place of origin on the sacred mounds of On (Table 1, 1. 25) while also asserting that the deceased king would cause the lapis lazuli plant (twn-plant of Upper Egypt) to sprout up (i.e., lotus) and tie the cords of the smsmt-plant (papyrus or lotus?) to unite with the heavens and maintain his power over the southern and northern lands (Table 1, 1. 26). In essence, the pharaoh would become Osiris/Nefertum-Ra in the afterlife, at which time he would lift the $z \hat{s} z \hat{s}$-flower and place himself "at the nose" of the Great Power (=lotus) while entering the Island of Fire (=Fields of Ra; Table 1, 1. 27).

Although the ankh is occasionally employed as a support for the sema-taui motif, as may be observed at Karnak and the Ptolemaic temples of Sobek and Haroeris at Kom Ombo (Baines 1975, Figures 138, 139 and 142), the symbol normally serves as the central and therefore focal element of the motif. Early executions of the sema-taui often place a lotus flower at the summit of the central pillar with Horus and Seth as flanking elements of the central shaft. The symbol varies, however, with respect to the terminal feature of the motif and the twin deities that support the central axis, especially after the turn of the second millennium. In many instances the blossom is replaced with either a pharaoh's cartouche (Figures 3b and 4a; (Baines 1975, Figures 133, 153 and 165)), the realistic image of a king (Figure 4b; (Baines 1975, Figures 128, 146b, 154, 155 and 166)) or and occasionally by Horus (Baines 1975, Figures 140 and 162) or Egypt's divine Ibis, Thoth (Baines 1975, Figures 128, 151 
and 155). In later depictions, the sema-taui is sustained by Horus and Thoth or twin Hapy figures (anthropomorphic gods that personify the Nile River's annual inundations; Figures $3 \mathrm{~b}$ and $4 \mathrm{a}, \mathrm{b}$; (Baines 1975, Figures 51, 52, 76, 88, 133, 153 and 154; Gillispie and Dewachter 1987, vol. 3, pl. 60.2)).

A derived and more common rendering of the sema-taui motif during the New Kingdom is observed on the hypostyle at Karnak of Seti I and his famous son, Ramesses II (1279-1212 BCE; Figure 4b), where an anthropomorphized image of Horus (=Khonsu to worshippers of Amen at Karnak) and Thoth, an ibis-headed figure, pull the vegetative ties of the sema-taui's central stalk. Although the lotus blossom of the central axis is now replaced by a kneeling image of Ramesses, we note that the young king's shoulder and chest are decorated with a blue-pigmented, petaloid lotus collar, as was the practice of interring pharaohs during this age (Schweinfurth 1884), ostensibly to identify a deceased king with his immortal lotus aspect in the afterlife. A similar image that decorates the thrones of Ramesses II inside the temple entrance at Luxor presents a sema-taui sign with twin Hapy figures (Figure 4a), these figures suggesting a Pyramid Text passage that identifies the Nile River's annual floodwaters (here personified by Hapy) as the unifier of the two lands of Ra (Table 1, 1. 28). This particular inscription identifies the two lands as the heavens and watery netherworld of the Nile instead of Upper and Lower Egypt, suggesting a dual meaning to the sema-taui motif.

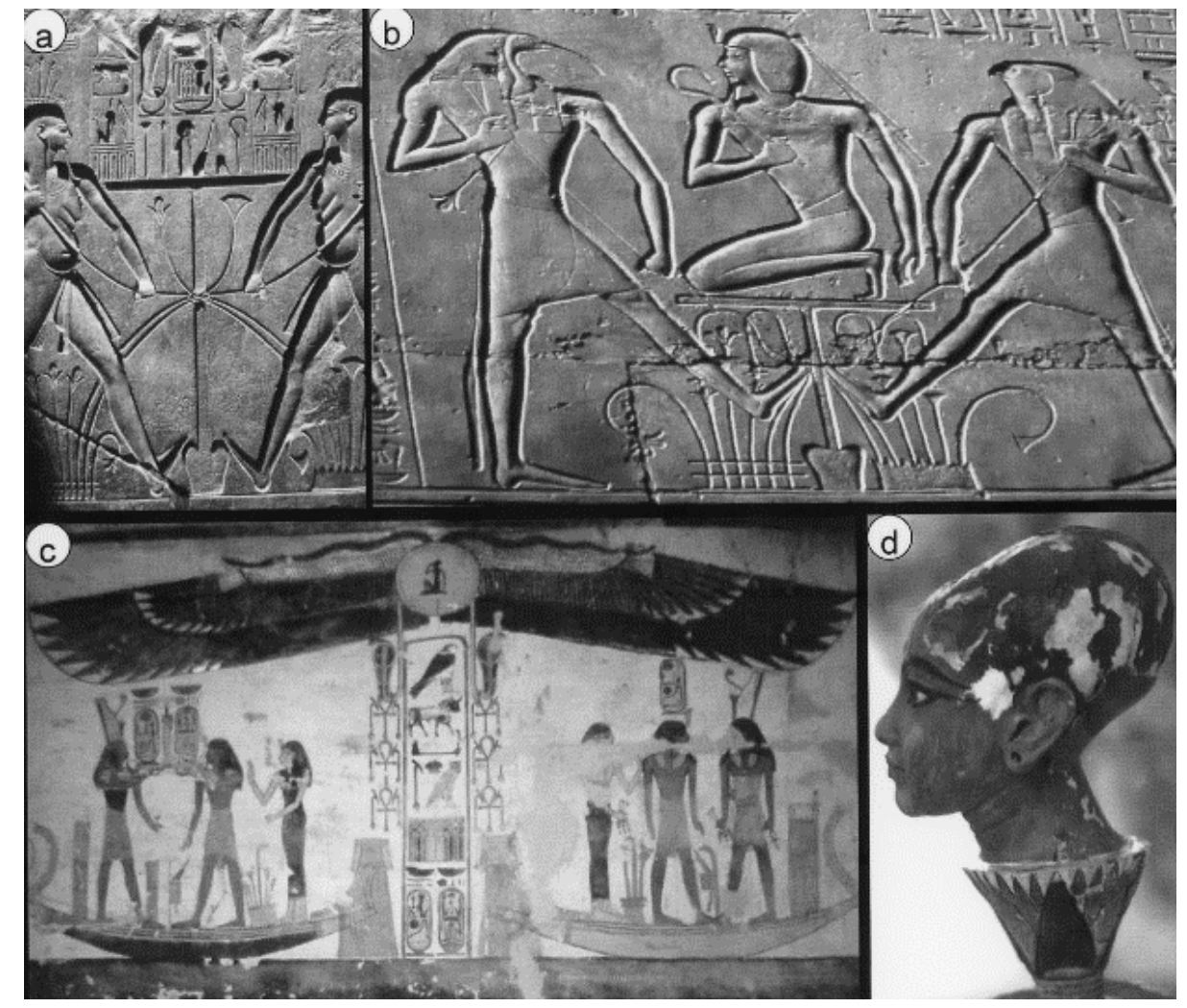

Figure 4. Union symbol (sema-taui) and ankh. (a) The cartouche of Ramesses II replaces a lotus flower on the central shaft of the sema-taui motif in Thebes. Twin gods (Hapy figures) that personify the floodwaters of the Nile River grasp the lotus and papyrus stems to support the axis mundi. Luxor, 13th c. BCE. (b) A kneeling image of Ramesses II replaces the sema-taui's lotus blossom in Thebes. Karnak, 13th c. BCE. (c) A winged disk that rises on an aquatic column in the Tomb of Ramesses IX is clearly symbolic of a lotus blossom instead of a solar orb. Twin cartouches of Ramesses IX ascend the lotus stalk and transform themselves into the living image of the solar/floral structure, inside of which is observed the image of the resurrected king as Harpocrates (personified Horus). The floral disk supports two cobras that dangle a triad of ankh symbols. Thebes, Valley of the Kings, Tomb of Ramesses IX, 12th c. BCE. (d) Egyptians believed their kings were reborn as lotus blossoms in the afterlife. Thebes, Valley of the Kings, Tomb of Tutankhamen, 14th c. BCE (Cairo Museum). 
The ribbed column (Figures 3a and 4a) and platform of the motif supports a collection of heraldic symbols, marking yet another departure from early conventions in lotus symbolism. Among these symbols is observed a stylized childish image of Ramesses as an alternative Egyptian symbol of eternal life: a shen loop (a rope that is tied at its base with two loose ends) flanked by two dangling serpents (uraei), each upholding a shen loop. As various historians have noted, the practice of placing a king's hieroglyphic birth or throne names inside a shen loop (the so-called 'cartouche' when elongated to accommodate the king's written name) identifies the pharaoh as both a god and possessor of eternal life (Wilkinson 1992, pp. 193, 195; Lurker 1980, p. 38), while the supportive shaft ostensibly symbolizes the lotus-god's phallus and stalk.

\section{The Shen Sign and King's Cartouche as Symbols of a Lotus Bud and Cosmic Egg}

Much like the ankh, the coiled rope that forms a shen loop is conventionally rendered in blue, while the enclosed solar orb is typically rendered in yellow, orange or red. Two shen loops are conventionally held by the talons of either Horus, the blue falcon, or Khepri, the ever-ascendant, blue-winged scarab beetle, and thus conventionally present a triad of golden disks: one exposed disk upon the head of the bird or beetle and two enclosed disks that are held in talons beside the creatures (Figure 1c,d). Since these symbols are often associated with ankh symbols and paired lotus buds and blossom, we are justified in interpreting this motif in terms of a recurrent lotus flower rather than a recurrent sun, for Egyptians often portrayed an open lotus blossom between two buds in order to symbolize the natural three-day blooming cycle of lotus blossoms (Figure 1c,d; (Emboden 1989a, 1989b; McDonald 2002; Wiersema 1988)).

We observe in the tomb of Ramesses IX a pair of uraei (divine cobras) that dangle from a pillared winged disk and support ankh symbols or shen loops (Figure 4c, also Figures $1 \mathrm{~d}$ and 3a); here, the shen may be envisaged as a bud-like incubus from which Egypt's celebrated sun gods-as a blue-petalled lotus, blue-winged god (note the aforementioned quotation from Denderah) or resurrected king-arise in the Fields of Ra. To confirm this interpretation, we need only refer to coffin inscriptions that speak recurrently of Horus, an earthly manifestation of Ra, hatching out of this cosmic egg within the "Isle of Flame" (i.e., the emergent hillock of On) to take the form of a blue-winged disk (Table 1, 1. 29). Other coffin inscriptions associate the egg with Egypt's divine ibis (Thoth) or another avian god, the "Great Cackler" (Geb, a divine goose; Table 1, 1. 30), the two birds sharing company with Osiris-Ra in the Nile's divine marshlands. In like manner, Horus is identified as a lord of eternity who "sprouts forth" from the egg in a watery abyss (Table 1, 1. 31), implying that the egg and lotus bud are equivalent entities.

The oft-neglected connection between the shen loop and inscribed cartouches (shenu) connote, therefore, a close relationship between the everlasting life of Nefertum's primordial phallus, blossom, and solar/floral "eye of $\mathrm{Ra}^{\prime}$ and the eternal recurrence of Egypt's celebrated dynasts. The emergence of Horus from his cosmic egg (or lotus bud) symbolizes the birth of a new king and dynasty on one level and yet also the passage of a king's soul (ka) to the paradisal Fields of Ra, the former concept applying to a famous rendering of Tutankhamen arising from a lotus corolla as an infant (Figure 4d) and the latter relating to the aforementioned tomb painting of Ramesses IX, on which the king's cartouche ascends the phallus of Osiris-Ra to assume his personified identity as Harpocrates (Horus) within a pillared winged disk (lotus flower; Figure 4c). This interpretation of the cartouche explains why the centralized lotus prop of the sema-taui on Chephren's throne (Figure 2c) is equivalent to the vegetative support of a king's cartouche or the king himself (Figure $4 a, b$ ). In both cases, the divinity and everlasting status of the king is symbolized by the eternal recurrence of the lotus. This general concept shares a close parallel in Mesopotamia, where a sacral lotus-tree is similarly identified with kingship, both generally and specifically (Annus 2002, p. 156; Kramer 1974; Parpola 1993). 


\section{Homologous Features of the Egyptian Lotus and the Fertile Crescent's Sacred Trees}

While acknowledging that the ankh emblem derives from, or at least shares a close symbolic association with the sema-taui symbol, in that both images symbolize the lotus plant and immortal life, it is notable that the latter sign shares essentially all the standard features with sacred tree images in the Near East after 1500 BCE. Sacral trees of the Levant and Mesopotamia usually exhibit: (1) a smooth and cylindrical central axis, (2) a terminal palmette, many bearing blue-pigmented appendages, (3) a surrounding configuration of smaller palmettes or campanulate floral motifs, and (4) a series or cluster of supple, lateral stems that tie directly to the plant's central shaft (Figure 5a-d; (Frankfort 1939, pl. 33; Giovino 2007, Figures 1-3, 13-18; Goodyear 1887, pl. 24; Jones [1856] 1995, pl. 15)). Such features constitute classic Neo-Assyrian trees of Ashurnasirpal at Nimrud (Figure 5b) and those that decorate the blue gates of Ishtar's temple in Babylon (Figure $6 a, b$ ), where the knotted stalks and terminal palmettes are linked by lotus buds. The resulting bud-and-blossom motif that links the canopies of three sacral trees clearly follows the recurrent pattern of associating lotus palmettes with sacral tree palmettes, as proposed by McDonald (2002, Figure 2a-d). Almost identical iconic trees are encountered on cylinder seals and early Assyrian murals at Kar Tikulti Ninurta that date from 1500-1200 BCE (Frankfort 1970, pp. 135-37).

The use of pigments in the execution of the early Assyrian trees at Kar Tikulti Ninurta as well as ceramics from Ashur (Andrae 1925) follow a similar color formula on Ishtar's gates of Babylon (Figure $6 \mathrm{a}, \mathrm{b}$ ) by presenting the palmette appendages as blue, the sepals as either blue or green, and the central disk as yellow. The use of pigments in the execution of early Assyrian trees at Kar Tikulti Ninurta as well as ceramics from Ashur (Andrae 1925) consistently depict palmette appendages as blue and/or white, the sepals as either blue or green and the central disk as yellow. The intensity of these colors invariably fades over the course of time and almost disappears completely on pieces in museum settings, but the full vitality of these color patterns is preserved on glazed bricks that Nebuchadnezzar II used to construct one of several 'gates' (walled portals) that led to the inner chambers of a principal temple complex in Babylon around 575 BCE. This structure was elaborated during the pinnacle of Neo-Babylonian influences over Mesopotamia and the Levant, during an age in which Nebuchadnezzar held Levantine tribes captive in the city, as is well documented in Hebraic records. The famous king dedicated his bright blue gate to the Babylonian 'Mistress of Heaven,' Ishtar, and covered its façade with an eclectic array of radial and lateral portrayals of the Nilotic blue lotus, a natural and often prominent denizen of marshy enclaves of the Tigris and Euphrates Rivers. Framed within variations on the Egyptian lotus bud-and-blossom motif (Figure 6b), depictions of mythic animals that represented Adad, Marduk and the Goddess established a mythical ambience for the practice of religion and kingship. The largest and most prominent representations of the stalked water lilies (Figure 6a) conserve the basic features of earlier Neo-Assyrian that are observed in the chambers of Ashurnasirpal II at Nimrud during the 9th c. BCE (Figure 5b), but with the unique Babylonian nuance of linking the terminal flowers of each tree with a running bud-and-blossom motif. Nebuchadnezzar's conventional use of pigments clearly follows a precise pattern that reflects the morphology of the Nilotic lotus (Figure 1c,d Figure 4c,d and Figure 7d) and mismatches with the natural coloration of date palm features (cream, green and brown). Interestingly, the aforementioned iconic trees share homologous characteristics with related symbolic trees from Persia and Central Asia during the 1st millennium BCE, as observed on a Scythian pectoral of gold from the same time period at Ziwiye, Iran (Figure 5c), which produces alternating lotus buds, blossoms and fruits. 


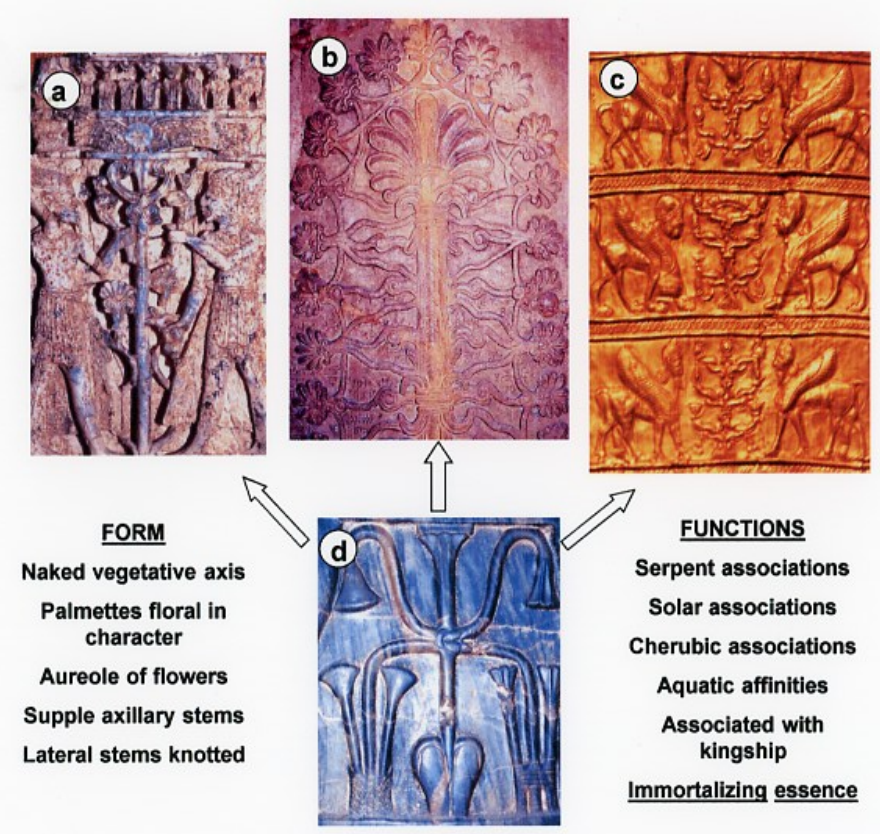

Figure 5. Shared features of the sema-taui symbol and Middle Eastern tree of life. (a) A Phoenician tree of life that was excavated from the Mesopotamian temple of Ashurnasirpal exhibits prominent Egyptian features: blue lotus palmettes, a blue-winged solar disk, and sun-bearing cobras. Yet the central stalk displays features of Mesopotamian trees of life: lateral palmettes, trefoil at the apex of the trunk, and corniculate lateral branches. Iraq, Nimrud, 9th c. BCE. (b) One of 170 sacral trees uncovered among the ruins of Ashurnasirpal II. Iraq, Nimrud, 9th c. BCE. (c) A series of three Perso-Aryan lotus trees of life terminate in a lotus blossom, solar motif, and lotus berry. The lateral branches of each tree support a succession of lotus buds, blossoms, and fruits. Chimeric guardians of the trees exhibit the combined aspects of a bull, lion, human, and eagle, suggesting the biblical features of a cherub. Iran, Ziwiye, 8-7th c. BCE (Metropolitan Museum). (d) Early Egyptian sema-taui motifs apparently served as a prototype to sacral tree imagery in the Fertile Crescent since both motifs exhibit a central stalk, terminal palmette, supple lateral stems that tie off to the plant's central column, and surrounding palmettes. Tree of life motifs similarly graced the backs and side panels of Mesopotamia and Levantine thrones and couches, usually as decorative ivory pieces (Barnett 1982, p. 25, pls. 18a,b, 52a,c; Crowfoot and Crowfoot 1938, p. 2; Parrot 1961, p. 155). Throne of Chephren, Giza, 26th c. BCE (Cairo Museum).

The famous blue gates of Ishtar at Babylon portray lotiform trees of life without a hint of ambiguity, but with Egyptian symbolic elements that now reflect the nuances of Mesopotamian iconographic craftsmanship. An interlinking series of water lilies that encompass the interlinking, stout trees conserve the ancient Egyptian bud-and-blossom motif by alternating flowers with opposing bud and blossom elements with flowers comprised of opposing full-blown flowers (Figure 6b). A running 'tendril' of water lily peduncles creates a continuous chain of floral motifs. This stylized composition is then reflected in a series of linked sacral trees at the center of the gates, in what may therefore be deemed the symbol par excellence of the widely celebrated goddess. The stout trunks are surmounted by a vertical configuration of three superimposed lotus tridents, the upper of which displays a bright radiate display of petals (Figure 6a). This common exhibition of three flowers likely represents that standard three-day duration of water lily anthesis. Between each of the stacked flowers is observed a tridentate lotus bud, whose drooping stalks create a standard symbol of everlasting life in Egypt and throughout the Fertile Crescent: recurrent water lily buds and blossoms. The sacral tree trunks emerge from a water line in the lower register and exhibit the familiar collars around the trunks, 
which conventionally serve as a point of connection between sacral trees and water lily blossom aureoles (Figure $5 b, c$ ).

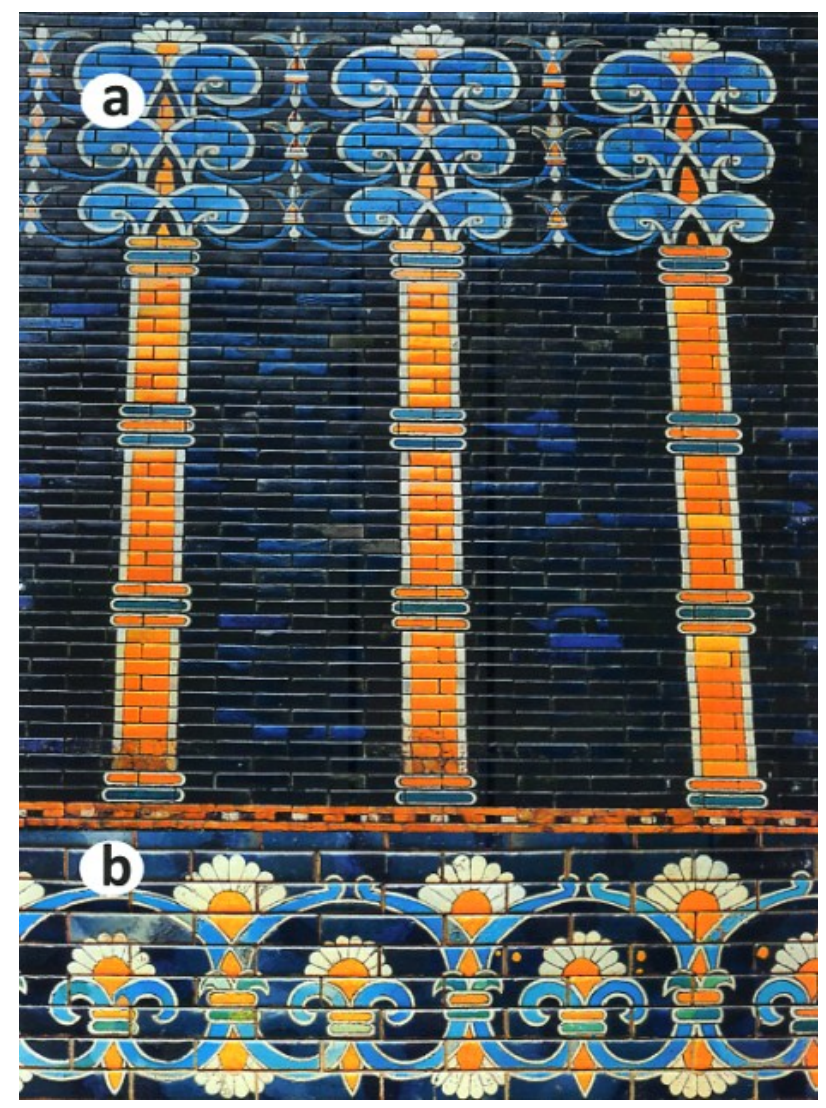

Figure 6. Details of Ishtar's gate. Babylon, ca. 575 BCE. (a) A row of lotiformed sacral trees with collared trunks and three terminal corollas are linked by stalked buds, connoting the symbolic theme of eternal recurrence, i.e., immortal life (Right Perspective Images/Alamy Stock Photo). (b) The linked trees are framed on four sides by variations on lotus bud and blossom motifs (MuseoPics-Paul Williams/Alamy Stock Photo).

Although various art historians have acknowledged Nilotic water lily imagery shares a common origin with sacral tree imagery (Coomaraswamy 1935; Danthine 1937; Goodyear 1887, 1891; Jones [1856] 1995, pp. 22-23, 28-29; McDonald 2002), modern commentators have yet to recognize an apparent relationship between the tethering of cosmic tree pillars with the use of water lily peduncles and knots to support the Egyptian lotus. Some historians have identified the lateral tethers as 'ribbons' or 'festoons' made of fabric (Garlick 1918; Giovino 2007, pp. 24, 87-88, 118), while others suggest these features represent watery tributaries and irrigation canals (Andrae 1925, p. 5). A less convincing interpretation identifies the knotted ropes as whirlpools (Porada 1945). Since a series of floral palmettes are obviously linked to the central pillared palmette with these supposed 'ribbons,' there is ample reason to ascertain these features as supple flowering stalks. And since the Egyptians employed the same feature in supporting their lotus stalks, in the symbolic context of supporting a regenerative life force, and often in association with winged disks and deities, we are obliged to recognize direct Egyptian influences over Assyrian sacral tree imagery.

Near Eastern sacral trees are recurrently associated with a solar motif (winged disk), just like their Egyptian homologues. And as noted by many authors and emphasized by McDonald (2002) and Parpola (1993), the Egyptian lotus and Near Eastern tree of life share close iconographic associations with winged and wingless serpents, lions, eagles, goats, humans, and bulls, often under the aura of an Egyptian-styled winged disk. 


\section{Roles of the Lotus in Funerary and Libation Ceremonials}

Since images of Mesopotamian and Levantine sacral trees are usually encountered within closely guarded sanctums of temples, it is abundantly clear that the symbol played a critical role in the practice of religion and the assumption of kingship. The same practice applies to the ankh and sema-taui signs among Egyptian temples and burial sites, and therefore compels us to question why these vegetation symbols share so many physical characteristics and functional roles in religious expression of the Nile and Fertile Crescent. Given the common occurrence of Egyptian symbols among Mesopotamian sites, including the ankh and sema-taui, there is no question that the artistic conventions of distant Egyptian communities were responsible for several developments in the evolution of sacral tree imagery. We have yet to explain, however, why so many successive societies employed lotus symbolism so frequently or why the palm tree and other Mesopotamian plant species played limited roles in Egyptian symbolism. Perhaps more importantly, we are bound to question why the lotus plant represented so many gods and goddesses in so many different times and places and how its form and function relates to cross-cultural conceptions of immortal life and aspirations to join the gods in the afterlife.

Although most references to the divine transformation of a king into a lotus flower apply to deceased individuals, there is also substantial evidence that a divine rite of passage to paradise involved a person's metaphorical transformation into a lotus flower in a ritualistic context. The transformational process and experiences were apparently performed within the inner sanctum of Egyptian temples. Various Egyptian textual sources that span 3000 years of pharaonic history, from the Old Kingdom to the Ptolemaic period, including the Pyramid Texts, Coffin Texts, and Book of the Dead (Table 1, 1. 32), describe the consumption of the solar eye of Horus by means of a libation or sacramental food ceremony. Upon performing the rite, the consumer gains passage to the sun god's riparian Fields of Felicity. Imbibing the sun god's vitalizing and immortalizing efflux (often translated as "water," "oil," "ointment," or "drippings"; Table 1, 1. 33; (Piankoff 1964, p. 42, pl. 5.47)) makes little sense if we consider the eye of Horus to be a solar orb, given that the god's eye arises from the Nile's aquatic underworld (Table 1, 1. 34). Moreover, the Nilotic sun has nothing but a profound desiccating, if not lethal effect on inhabitants of the Nile River. On the other hand, the allusion seems sensible if we envisage the solar eye as a lotus flower, given that lotus flowers produce copious amounts of sweet-smelling nectar on their first day of anthesis (McDonald 2002; Schneider 1982; Wiersema 1988) to wash pollen grains off their insect visitors. Countless friezes and paintings suggest that the king imbibed a fluid that was identified with an "efflux" from the eye of Horus (Figure 1c,d), otherwise associated with the solar semen or seed of Osiris-Ra and Ra (Figure 7a). Perhaps this is why the Pyramid Texts refer to the 'eye of Horus' as the sweet-smelling, sweet-tasting, blossom of Isis (i.e., blue lotus; Table 1, 1. 35). 


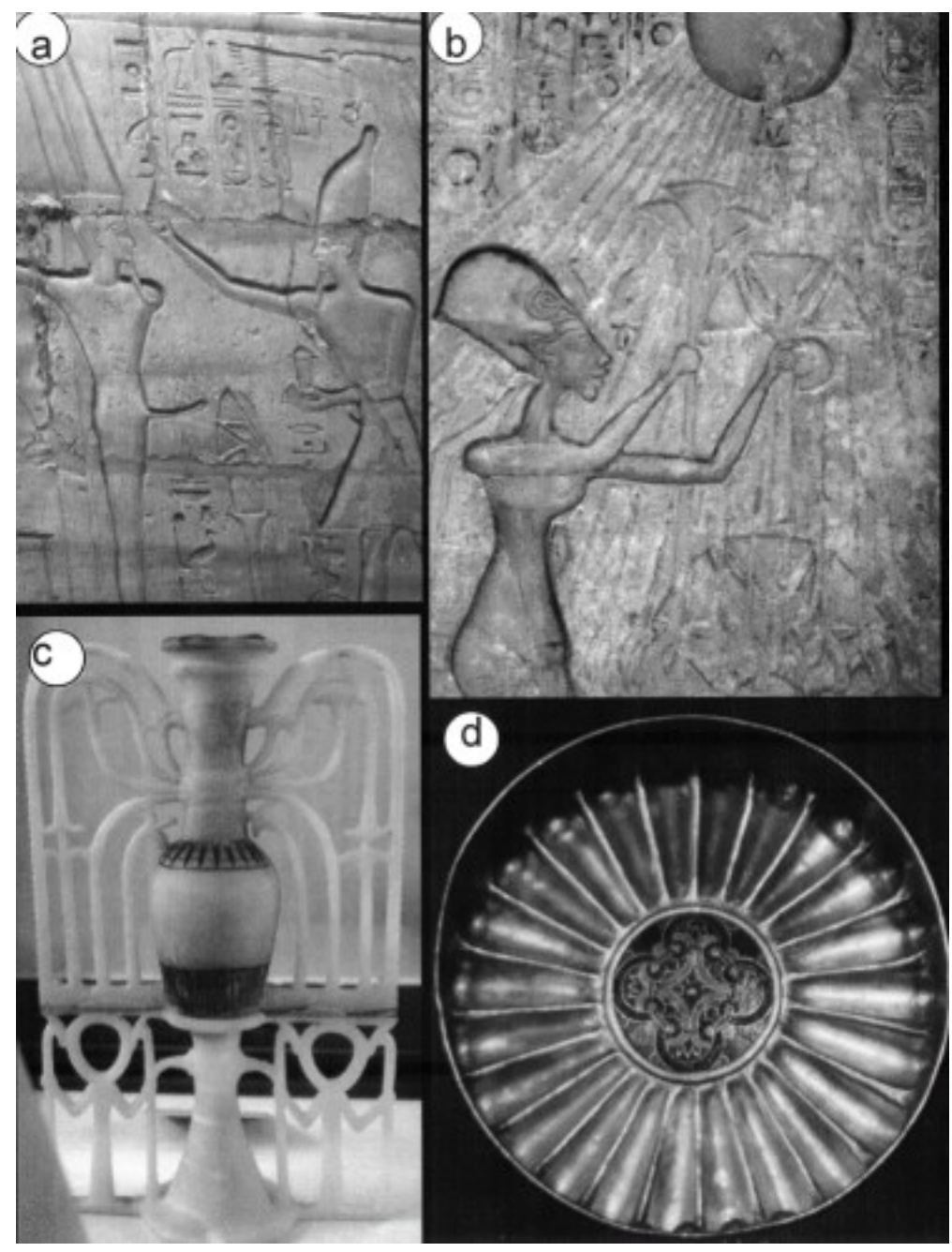

Figure 7. Lotus extracts in funerary rituals. (a) A lotus-libation scene at Luxor suggests that the king partook of a libation that was identified with the semen of the sun/lotus god, Min (an aspect of Amen). Karnak, 13th c. BCE. (b) The famous heretical sun worshipper, Akhenaten, enjoys the breath of eternal life (ankh to nose) as he upholds lotus blossoms to the sun during a libation ritual. El Amarna, 14th century BCE (Cairo Museum). (c) The contents of unguent vessels in the tombs of Egyptian kings were often identified with lotus stalks and flowers, life (ankh motifs), and everlasting sovereignty over Upper and Lower Egypt (sema-taui symbol). Thebes, Valley of the Kings, Tomb of Tutankhamen, 14th c. BCE (Cairo Museum). (d) Libation cups and goblets in Egypt and the Middle East were often decorated with, or depicted as, lotus blossoms. Tanis, Tomb of Psusennes I, 10th c. BCE (Cairo Museum).

Lotus nectar may well have been the substance to which the mythology of On alludes in a reference to the invigorating semen of the sun-god Nefertum, as we observe the king in reliefs at Luxor and elsewhere partaking of an ithyphallic god's ejaculum as it spills over lotus flowers and libation vases (Figure 7a; (Gillispie and Dewachter 1987, vol. 3, pls. 36.5, 36.6, 47.1)). Similar images occur throughout Egypt, and clearly relate to the ubiquitous associations of lotus stalks with libation vases and urns that appear first during the Old Kingdom (2649-2150 BCE) at Saqqara during around 2500 BCE. Lotus libation scenes only increase in frequency during the Middle and New Kingdoms (ca. 2050-1100 BCE) at Thebes, Abu Simbel and Abydos, and are encountered no less frequently at Kom Ombo, Edfu and Meroe from 300-100 BCE. According to various textual sources, this rite allowed priests to revive and refresh themselves with truth (maat), wisdom, and joy ((Piankoff 1968, p. 46); Table 1, 1. 36). 
A more personal and detailed account of a libation ceremony is described in a relatively late Demotic text (3rd c. CE; (Betz 1986, PDM xiv. 1-92)) that describes a young initiate's experience of ecstatic exhilaration upon drinking the sacramental beverage. The initiate relates that he is transported to the primeval waters and netherworld of the gods after transforming himself into a ram-lion-lotus god known as Amun. Proclaiming the secrets of the underworld have been revealed to him and that the libation has opened his eyes to the divine light of a lotus flower, his soul ascends from the netherworld into a celestial sphere of light, upon which he shouts, "Oh Lotus, open to me heaven in its breadth and height! Bring me the light which is pure" (Betz 1986, PDM xiv. 862-65). Euphoric experiences of such type lend credence to the perennial hypothesis that psychoactive principles of water lilies were possibly employed as a shamanic medium (Emboden 1979, 1981, 1989a, 1989b; McDonald 2002; McDonald and Stross 2012).

Egyptian libation scenes are commonly observed on temple and tomb walls, papyri, thrones, and coffins, suggesting that drinking lotus nectar (or perhaps extracts of water lilies, as suggested by (Emboden 1989a, 1989b)) within the inner sanctums of Egyptian temples was as common in burial rituals as it was in daily life (Lange and Hirmer 1968, Figure 226; Gillispie and Dewachter 1987, vol. 3, pl. 15). Numerous lotiform libation cups and vases were unearthed, for example, from the tomb of King Tutankhamen (Lange and Hirmer 1968, pl. xxxiii), some alluding in script to the king's achievement of immortal life (Assaad and Kolos 1979, p. 32; Fox 1951, pl. 3). One such vessel is a long-stemmed alabaster drinking cup fashioned in the image of a lotus corolla (Desroches-Noblecourt 1989, Figure xxiia), while another common vessel type is an alabaster 'oil vase' fashioned as a sema-taui symbol (Figure 7c). The central axis of this receptacle is decorated with a lotus perianth, implying that the vessel contains the essence (or semen) of the floral eye of Horus. These vessels compare closely with libation lotus cups in a ritual scene on a golden shrine of King Tutankhamen and Queen Ankhesenamen, where the convivial couple is observed sharing a libation with lotus flowers and buds in their hands (Lange and Hirmer 1968, pl. xxxiii).

Only a few centuries later, in the Tomb of Psusennes at Tanis (11th c. BCE), we encounter a distinctive lotus vessel made of gold, but this particular cup bears all the features of a Mesopotamian vessel (Figure 7d). While it is difficult to say if the vessel was obtained as a gift or spoil of warfare, the four-cornered lotus motifs in the center and the fluted walls of the vessel match closely with libation implements and lotus-cup imagery at Nimrud, Iraq and throughout the Middle East. Since we observe numerous examples of libation scenes with lotus flowers at Edfu, Kom Ombo, and Philae during the later Ptolemaic and Greco-Roman periods, we can only conclude that lotus flowers played a central role in libation ceremonies for thousands of years.

\section{Lotus-Libation Scenes in the Near East}

Almost identical lotus-libation scenes are observed on ivory plaques and steles at Megiddo (Palestine) and Ras Shamra (Syria) from the 16th-13th centuries BCE (Loud 1939, pls. iv.2b, xxxii.160; Keel and Uehlinger 1998, p. 65, Figures 65, 67 and 68a; McDonald 2002, Figure 7b,c), and frequently so among friezes and art objects from the Near East, Mesopotamia and Persia during the first millennium BCE (McDonald 2002, Figure 7d; Mazar 1961, vol. 2, p. 270; Roaf 1998, p. 163; Strommenger 1964, Figures 194, 195 and 241). The ritual can also be linked indirectly to the cult of Yahweh during the age of Solomon (ca. 1000 BCE), for the stone sarcophagus of the Phoenician Ahiram of Byblos, a predecessor to the Phoenician builder of Yahweh's first temple in Jerusalem, Hiram of Tyre, portrays the king in the act of drinking a lotus libation (Mazar 1961, vol. 2, p. 143) while sitting on a seraphic/sphinx throne that matches closely with biblical descriptions of Solomon's "mercy seat." A lotus bud-and-blossom motif (an Egyptian symbol of immortal life) surrounds the lid of Hiram's casket.

We can be sure that the practices of Solomon's regional allies were not discouraged in Jerusalem during this historical era, for biblical records make clear that Yahweh's first temple was constructed in part for the benefit of Egyptian, Canaanite, and Middle Eastern gods and goddesses (I Kings 11: 4), despite prior prohibitions to such practices during the Mosaic age (Exodus 34: 11-13; Deuteronomy 
16: 21; Judges 3: 7; 6: 25, 28; Jeremiah 44: 3-6). Like many kings of his day, Solomon accepted female concubines from distant lands to consummate peace accords with former or potential adversaries; since these consorts were not expected to renounce the religious traditions of their homelands, Solomon promoted the offering of incense and sacrifices to Astarte (Ishtar) of the Sidonians, Chemosh (=Shamash, a Mesopotamian sun god represented iconographically as an Egyptian winged disk above sacral tree motifs) of the Moabites, and Molech of the Ammonites (1 Kings 11: 5-8). Biblical records also indicate that Yahwists participated in the worship of various Near Eastern goddesses and their vegetative symbols during and shortly after Solomon's reign (Patai 1990, p. 32; Keel and Uehlinger 1998, p. 152; Wiggins 1993, p. 30; James 1966, p. 181), along with sacred prostitution in temple complexes (1 Kings 14: 23; 2 Kings 17: 10; 23: 5-7; Jeremiah 17: 1-2; Hosea 4: 12-13), all of which were practices employed by contemporaneous religions of Mesopotamia and the Levant.

Hebraic records acknowledge that Solomon, just prior to his temple's construction, accepted into his harem the daughter of an Egyptian pharaoh (1 Kings 3: 1; presumably an offspring of Psusennes), for whom altars were established on "high places" to honor the Egyptian pantheon. In Ezekiel's vision of Yahweh's first temple, worshippers wept for Tammuz at its northern gate (Ezekiel 8: 14) and bowed before the sun at the eastern gate while "putting the branch before their noses" (Ezekiel 8: 15-17). The latter allusion can only refer to the Egyptian and Mesopotamian practice of worshipping the sun while placing an aromatic lotus flower before the nose, as we encounter frequent portrayals of such practices on scarabs and ivory etchings in ancient Canaan (Keel and Uehlinger 1998, p. 86, Figure 107). Moreover, Hebraic devotions to Mesopotamia's famous god of aquatic vegetation, Tammuz (=Dumuzi of Sumeria), a close associate of the Mesopotamian sun god, Shamash of the Moabites, is of particular interest in this connection, because this god was recognized mythically as a guardian of the blue-leaved (=blue-petalled?) tree of life, the kiskanu plant of ancient Eridu and Ur (James 1966, pp. 8-10; Langdon 1914, pp. 30, 114; Langdon 1928; McDonald 2002). It is also noteworthy that Eridu is very close to the biblical garden East of Eden in the land of Ur and that Tammuz was the wife of Ishtar, the Mesopotamian equivalent to Astarte in Sidon, where Hiram built temples in her honor (Durdin-Robertson and Durdin-Robertson 1979, pp. 53, 126).

Around the age of Solomon, we are aware that the Assyrian "Myth of Adapa" was in circulation and that this tale recognized Tammuz and his close associate, Ningizzida, as the "Lord of the Good Tree" (Black et al. 1992, p. 138). This divine pair served as guardians to the gateway of heaven, in which role they thwarted the efforts of mortal men to attain immortality by tricking the human offspring of the god Enki, Adapa, the "seed of humankind" (the equivalent of biblical Adam; (James 1966, p. 72)), into passing up an opportunity to consume the food and water of the gods (presumably from the tree of life; (Pritchard 1969, p. 102)). Obviously, similar mythic themes are echoed in the book of Genesis.

\section{The Hebraic Dimension}

Numerous biblical scriptures allude to the erection of wooden idols and "pillars" known as asherim and mazzeboth in the Temple of Solomon to pay obeisance to the creators of the Ugaritic pantheon, El (Baal) and Asherah (1 Kings 15: 12-15; 19: 18; 2 Kings 10: 18-24; 2 Chronicles 15: 16; 33: 1-7). According to Hebrew tradition, these customs were outlawed by Moses after his epiphany on Mount Sinai (Exodus 34: 13; Deuteronomy 12: 2-3; 16: 21; Judges 3: 7; 6: 25-28), but the prophet's divine edicts proved futile in discouraging religious tolerance and polytheistic inclinations of his tribal associates and descendants. Biblical references to the erection of idols and asherim appear to relate to sacral tree worship since, from a scriptural and iconographic point of view, the 'poles' (mazzeboth) of Baal and 'pillars' (asherim) of Asherah (whose word-roots obviously share a common origin), were undoubtedly plant symbols (Wiggins 1993, pp. 14-15, 93-97) and must surely relate to pillared sacral tree motifs in archeological records of this day. Such practices were apparently shared by the Egyptians, insofar as the famous pharaoh, Rameses II, had a pillar dedicated to Asherah's daughter, Anat, at Beth Shean during the 13th c. BCE (Cassuto 1971, p. 65). Not only did the idolizing of asherim relate to the practice of "tree worship" (Deuteronomy 16: 21; 1 Kings 14: 23; Hosea 4: 12-13), but the erection of 
these effigies is described in terms of a "planting" (Deuteronomy 16: 9) and their destruction as an "uprooting" (Micah 5: 14) or a "hewing down" (Exodus 34: 13; Judges 6: 25, 28, 30; 1 Kings 15: 13; 2 Kings 23: 14; 2 Chronicles 14: 2-4; 15: 16).

Art historians are justified in drawing a direct link between the proto- and stereotypical images of Near Eastern fertility goddesses and stylized images of the sacral tree (Keel and Uehlinger 1998, pp. 199, 234, Figures 9-72, 214, 215 and 233a,b); or indeed, McDonald (2002) goes so far as to identify Asherah as a lotus goddess (Patai 1990, p. 59, pls. 13, 15, 16, 27), if not the personification of the Nilotic lotus. Not surprisingly, this goddess and her daughter, Anat, as well as Kadesh (Mazar 1961, vol. 2, p. 66; Patai 1990, pl. 25) and Astarte/Ishtar (Patai 1990, p. 59), exhibit hairstyles and the general aspect of Egyptian goddesses and are frequently associated with lotus flowers and serpents, which had formerly and contemporaneously related iconographically to standard images of Isis, Nephthys and Hathor of ancient Egypt. As earlier noted, these same goddesses were assimilated into the Egyptian pantheon long before the age of Solomon. Because these effigies are conventionally executed in a columnar form and occasionally wear lotus crowns, historians justifiably draw a direct connection between the goddess Asherah and the Canaanite/Hebraic asherim. Moreover, many of these figurines are charred, recalling Hebraic records that recommend the burning of false idols as an act of penitence (2 Chronicles 15: 16).

Given that the Temple of Solomon was constructed by a Canaanite king to serve a host of Egyptian and Near Eastern gods and goddesses, it should come as little surprise that Solomon's house of worship shared features with temple constructions in Egypt and the Middle East. Detailed descriptions of the temple in the biblical books of Kings and Chronicles make clear that the rooms were filled with images that relate to the Egyptian lotus and sacral trees of the Near East. Solomon's temple entrance was framed, for example, with two large pillars whose capitals were decorated with "lily-work" (1 Kings 7: 16-22, 26; 2 Chronicles 4: 5). We can rest assured that the floral designs were based on the Egyptian water lily because the Hebrew word for the flowery capitals, shushan (=susa, shushan-eduth, shoshannim, shoshanah, (Moldenke and Moldenke 1952, pp. 41-43, 154; Walker 1957, p. 226)), is clearly cognate with Coptic shoshen and Arabic sousan, deriving from an Egyptian word for the Nile's blue water lily, sheshen (Anthes 1959; Darby et al. 1977, vol. 2, p. 633; Wilkinson 1992, p. 121). Predictably, the hieroglyph for sheshen, a logograph, is a lotus shoot. In all likelihood, pillars with lotus capitals shared a symbolic relationship with the famous asherim. In this same connection, Coomaraswamy (1935, p. 104) suggests the pillared lotus capitals of Egypt and Greece, with symbols of Heaven above and Earth below, are essentially "cognate in form and coincident in reference." And to be sure, an image that marks the entrance to the Judaic holy of holies is of paramount importance.

In addition to the vegetative symbolism in Solomon's temple, Near Eastern animal symbolism associated with sacral trees also comes into play. The antechamber of Solomon's temple contained, for example, a giant bronze basin that bore Nilotic lotus petal engravings on its outer rim and was supported by a base formed by twelve bronze bull figures. Triplets of bovine forms that faced the four cardinal points of the cosmos (I Kings 7: 23-26) suggest that early Yahwists in Jerusalem held little regard for the admonitions and warnings of Moses in the book of Exodus. Since biblical records state specifically that the bronze basin symbolized the sea, and we know that Phoenician traditionalists identified the goddess Asherah as a sea goddess and her consort, Baal, as a bull (Cassuto 1971, p. 58), it seems clear that Solomon's bath was fashioned in the image of mythic and iconographic themes that were borrowed from Ugaritic associates in Tyre (Keel and Uehlinger 1998, p. 169).

It also seems more than coincidental that the most prominent images in Solomon's sanctuary were those of the cherubim, a mythical class of heavenly creature that Yahweh appointed as the protector of Eden's tree of immortal life (Gen 3: 24). Images of these creatures dominated the inner confines of Solomon's temple, including the Holy of Holies, where the ark of the covenant was guarded from the outside world. Solomon received the voice of Yahweh directly from this mysterious container (Patai 1990, p. 82), not unlike Moses before him (Numbers 7: 89) and as Ezekiel soon thereafter (Ezekiel 10: 5). The Book of Kings emphasizes the fact that these creatures were rendered large 
in scale and that they touched their outstretched wings (1 Kings 6: 26-27; 2 Chronicles 3: 7-12), suggesting the Egyptian practice of portraying Isis and Nephthys, the sisters of Osiris-Ra, with their wings held together on the 'arks' of Horus and Egyptian pharaohs (Gillispie and Dewachter 1987, vol. 1, pl. 11.4; vol. 2, pl. 35.7; vol. 3, pl. 32.5; vol. 4, pl. 24.2), which were paraded around temple grounds during religious holidays. Equivalent motifs are found among Levantine ivory plaques (Frankfort 1970, Figure 378). Other scriptures note that cherubs occurred on blue curtains that shrouded the Holy of Holies (2 Chronicles 3: 14) - a feature dating from the Mosaic age, when the ark of the covenant was shielded in the tents of nomadic Hebrew tribes (Exodus 26: 1; Numbers 7: 89)-and on the ark of the covenant itself (2 Chronicles 5: 7), as well as the mysterious "mercy seat" depicted on the ark (Exodus 25: 17-22; 37: 6-9; (Mazar 1961, vol. 1, p. 162)).

Although the latter verses do not specify the physical nature of the cherub, Ezekiel's vision describes this creature in terms of a chimera that bore the "faces" (aspects) of an eagle, lion, bull, and man (Ezekiel 1: 4-11; 10: 14) or simply of a man and lion (Ezekiel 41: 18-23). Such descriptions call to mind, of course, either an Egyptian sphinx or the two massive creatures that stood guard at the entrance of Ashurnasirpal's palace (Layard 1849, vol. 2, p. 464; Mazar 1961, vol. 3, p. 159; Roaf 1998, p. 163; Ward 1910) and conventionally before the lotus-flowering boughs of cosmic trees in the Middle East, as observed on Ziwiye's lotus-trees of life (Figure 5c) and the armrests of Levantine thrones (McDonald 2002, Figure 7b). At Til Barsip (Tell Ahmar), a similar creature with blue wings is followed by a priest that upholds a blue-petalled water lily (Parrot 1961, Figure 110). Since these figures are obviously based in part on Egypt's ancient image of a sphinx and this creature's close lotus associations, we are given to identify biblical cherubs as the chimeric forms that flank lotiform trees of life, usually in pairs, throughout the Near and Middle East (Frankfort 1970, Figures 187, 196, 218, 224, 380, 381, 391).

\section{Felling the Asherim}

The use of lotus and cherub imagery in the temple of Yahweh, along with the worship of vegetative asherim, suggests that Hebrew communities likely employed sacral tree imagery to the same extent as their historical associates in Assyria, Babylon, and Phoenicia. Such customs came to an end in Judah, however, during the reign of Josiah (ca. 620 BCE), at which time prohibitions against the manufacture and use of graven images were more strictly enforced (II Kings 23: 3-20). The historical reason for this radical change in tradition is still a matter of debate, but the Old Testament is consistent on the issue. In the original establishment of Mosaic law, it was stipulated that Yahweh would allow no other gods be held before him, and that the Creator's protection of Hebrew tribes against the onslaughts of Amorites, Canaanites, Hittites, and Midianites would be withdrawn if they continued to pay homage to foreign gods (Exodus 34: 11-13; Leviticus 26: 1; Judah 6: 25, 28). The same general terms applied during the 7th c. BCE reformations of Josiah, and thus required of Hebrew communities the abandonment of former religious practices. Paradoxically, the enforcement of Mosaic laws resulted in the removal and destruction of the magical serpent-rod (nehustan) of Aaron and Moses (2 Kings 18: 4) "from high places." That Hebrew communities would continue to hallow Mosaic doctrine and yet destroy one of the patriarch's most significant possessions is of considerable interest, in that it demonstrates that post-exilic Hebrews were historically ambivalent to aspects of their past, some of which were deemed sacred and others profane, at least in terms of post-exilic Hebraic perspectives on Near Eastern history.

The destruction of Moses' brazen serpent is of particular relevance to the present discussion on two counts; first, the implement was likely Egyptian in origin, given that the priests of the pharaoh employed the same sort of staff when they matched their powers of magic against the powers of Moses (Exodus 7: 8-20); and second, the Egyptian staff was likely associated with the "lotus-scepter of Ra" (Piankoff 1974, spell 1090), since Egyptian kings and priests frequently upheld a lotus staff that was encoiled by a divine cobra during mortuary and religious rites (Budge [1931] 1970, p. 166; Lange and Hirmer 1968, pl. li; El-Mallakh and Bianchi 1980, p. 44). These images relate, no doubt, 
to the habit of associating Horus with a lotus flower and serpent (as noted in the aforementioned inscription at Denderah; Table 1, 1. 37; (McDonald 2002)). In this connection, it is interesting that biblical records never state explicitly that the rod of Aaron was inherently evil, but that Jews had sinned by presenting offerings directly to the staff. This particular detail compels us to wonder if the destruction of the asherim resulted primarily from the worship of false idols instead of an aversion to lotus-tree symbolism.

However strong the resistance to Canaanite idols and symbolism during Josiah's reforms may have been, there are no overt or even implicit biblical prohibitions to the traditional use of lotus symbolism. This is somewhat surprising because the plant was widely employed as the principal symbol of many prohibited gods and goddesses of Egypt, Canaan, and Mesopotamia. Similarly, we encounter many negative references to the act of tree worship and idolatry in the Bible, but no direct references against the associated practice of libation ceremonies per se. While it is stated that the burning of incense and the pouring of libations in honor of the "Queen of Heaven" (Astarte/Anat) was sinful (Jeremiah 44: 14-22), it is abundantly clear that similar practices played an important role in Judaic ritual following the exile in Egypt. For, had not Jacob offered libations before a sacred pillar in pre-Mosaic times (Genesis 35: 14)? And had not members in the tribe of Moses celebrated similar practices in front of the ark of the covenant (Exodus 25: 29; 2 Chronicles 5: 5)?

During the advent of the post-exilic period, it is noteworthy that the famous Persian dynast, Cyrus (Koresh), was glorified by the Jews on account of his role in releasing the Jews bondage in Babylon and the repatriation of Jerusalem's cherished libation vessels (Ezra 1: 7-11). Cyrus was therefore promoted to the exalted status of an "anointed one" (messiah) of Yahweh (Isaiah 45: 1), ostensibly placing him on equal footing with Jesse, David, and Solomon. This tribute seems exceedingly generous when we consider that Cyrus did not worship Yahweh in Persia, but probably paid allegiance to Ahura Mazda, the creator of the Zoroastrian pantheon. We can be sure that Cyrus worshipped Ahura Mazda, for Cyrus had Median ancestry and sired children that bore the names of Gathic (Zoroastrian) personages: Hystaspes/Vistaspa and Atossa/Hutaosa. Moreover, Zoroastrian fire altars have been found among the ruins of Pasargade. That Hebrew communities would chastise all outsiders that held a god before their own and yet recognize a Perso-Aryan dynast as a divine personage seems to demonstrate, once again, a certain degree of compromise and ambivalence regarding the application of reformation doctrines and foreign religious practices in post-exilic Judah.

In later days, pseudepigraphal works also make reference to libation ceremonies, as evidenced by a hymn from the Odes to Solomon (number 11), which refers to a plant of the Lord that "spilt" its holy spirit and its "living" and "speaking" waters, making Solomon drunk with knowledge and filling his nostrils with the aroma of the Lord (Barnstone 1984, p. 273). Such reports appear to echo the aforementioned Egyptian notion of imbibing truth (maat) from the waters that spill from the eyes of Horus, a concept that is portrayed iconographically by streaming ankh symbols. Another song refers to a sweet cup of milk as the delight and "Son" of the Lord; those who drink of this cup are near his right hand, the traditional locus of Yahweh's tree of life (Barnstone 1984, p. 279).

It is of considerable interest, therefore, that before the last vestiges of pharaonic Egypt were eclipsed by religious and cultural traditions of Semitic origin (i.e., Christianity and later Islam) around the 2nd c. CE, vestiges of Egypt's traditional habits in ritual and symbolism persisted in a syncretistic manner for several centuries. The earliest known visual impressions of the Christian cross and tree of life derive from Coptic traditionalists along the Nile River around 200 CE and reveal a nascent school of Christian artistic expression that continues to borrow conservatively from ancient Egyptian lotus imagery and symbolism. An exemplary stele from the second century associates the cross of Christ with the Greek letters alpha and omega, a Mediterranean symbol for immortal life, and thus indicates growing European influences over Nilotic culture (Figure 8). While the symbolic relationship between the cross, tree of life and Greek letters is biblical, art historians have yet to acknowledge that a five-membered palmette that surmounts the cross derives from lotus blossom imagery and clearly establishes a transition between Egypt's traditional past and its Christian future. We note that the same 
five-membered perianth reappears in a radial configuration on either side of the cross, each being placed within the loop of the ankh symbols (or crux ansata = 'cross with handle'), precisely where Egyptians had traditionally placed the lotus flower (Figure 3a). In this case the two ankhs assume a quasi-personified aspect by wearing Christian robes and upholding two additional crosses and stylized grape leaves. The latter vegetative motif relates, of course, to scriptural passages that equate Christ as the grapevine of life (John 15: 1, 4-5), much as his blood is equated with wine during celebrations of the Eucharist, the imbibement of which confers immortality in the afterlife. Hence the ancient Egyptian ankh symbol, now the Latin crux ansata, was identified with the Messiah, the sacrificial cross, the Nilotic lotus, the blood of Christ (i.e., grape leaf as the source of wine), the tree of life and related concepts of attaining eternal life. The practice of the eucharist may well have seemed consonant during this age with earlier performances of lotus-libation rituals in ancient Egypt, as they both were esteemed as religious expression of the highest order and apparently served a similar religious purpose, i.e., achieving immortal life. Such possibilities must be considered hypothetical, however, until connections between the Christian concepts of the tree of life and the Nilotic lotus are explored more rigorously in both written and iconographic records from Egypt's Christian dawning. A key to such inquiries will hinge, to be sure, on a more complete understanding of the time-tested role of water lilies in libation ceremonies in ancient Egypt, Mesopotamia and the Levant.

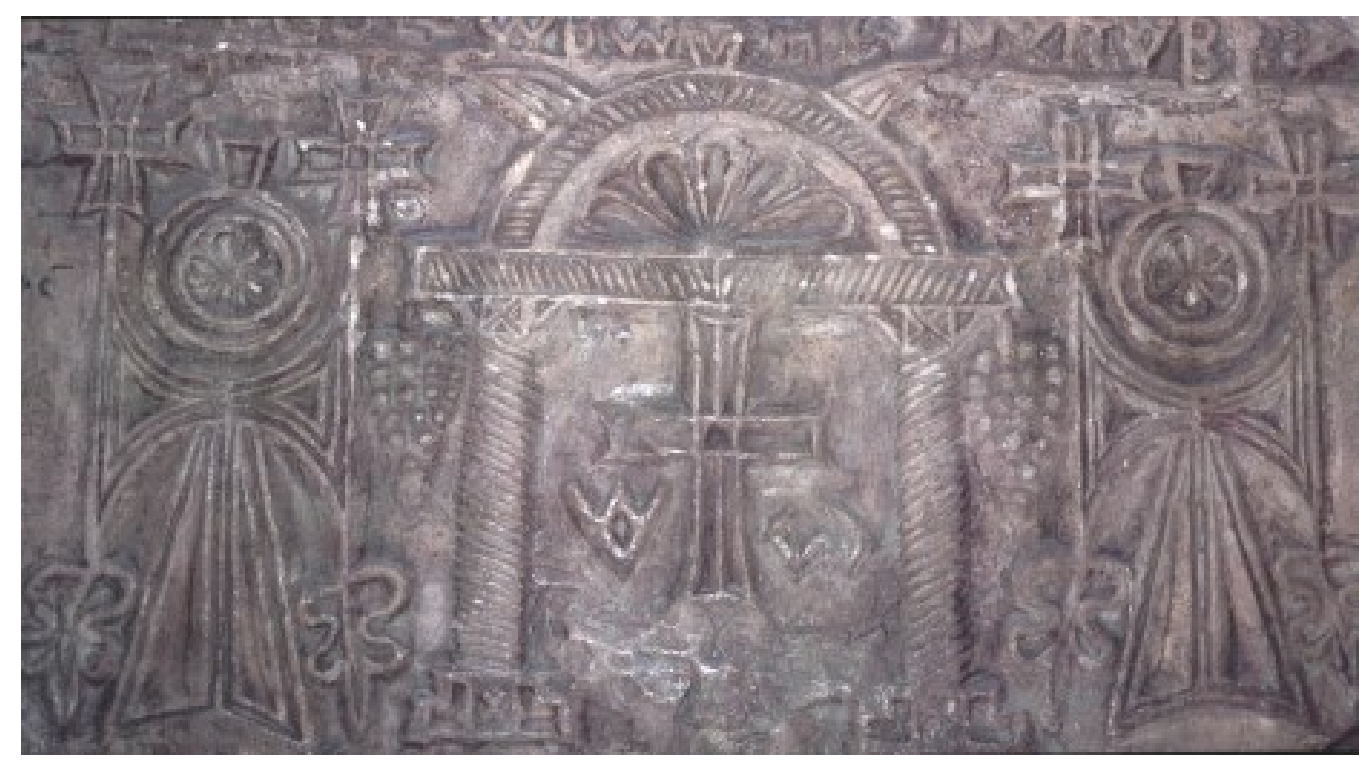

Figure 8. Lotus, ankh, and Coptic cross. Early Christian communities in Egypt symbolized the cross of Christ with their traditional ankh symbol. Note that the cross of Jesus-here identified with the Greek letters alpha and omega-supports a five-petaled palmette, radial views of which are observed within the "handle" (the Egyptian shen loop) of the crux ansata. The quasi-personified ankh signs, apparently emblematic of Christ himself, wear robes and uphold crosses and dangling grape leaves. Cairo, 3rd c. (Coptic Museum).

\section{Discussion}

Mythic and artistic themes that relate to an immortalizing plant of the gods are shared throughout Egypt, the Levant and Mesopotamia. While one school of thought maintains that the biblical tree of life bears no direct relation to sacral tree imagery in Mesopotamia (Black et al. 1992, p. 171; Parpola 1993) and another admits to historical connections between mythic tree of life motifs in Egypt, the Mediterranean and Mesopotamia (James 1966), resolution of these competing views requires coherent arguments that explain both how and why so many distant human populations came to share so many mythic and iconographic conventions. 
A comprehensive consideration of lotus symbolism in ancient Egypt, the Levant and Mesopotamia, in light of the plant's unique biological attributes and behaviors, serves to accentuate the profound and influential roles this iconic plant once played in early developments of ritual and religious expression on an international basis. We have long been aware that the Nilotic lotus pervaded and dominated iconographic and mythic records of ancient Egypt from 2500 BCE to the early centuries of the common era, and that the plant served as a symbol for living creation and the everlasting life of the sun, solar deities and pharaohs. But the degree to which closely related developments of lotus symbolism in the Middle East borrowed from, or paralleled those of ancient Egypt from around 1500 BCE is poorly explored. While less definitive evidence suggests that the plant played a critical role in mythic and religious traditions in the Tigris-Euphrates Valleys around 2500 BCE (McDonald 2002), the abrupt and abundant appearances of Egyptian lotus imagery among important Levantine urban centers around $1500 \mathrm{BCE}$, especially with respect to carved ivory decorations on thrones, aristocratic furniture and temple walls, seems to anticipate the widespread adoption of Egypt-inspired lotus symbolism on large scales in the guise of iconographic 'sacral trees' at Kar Tikulti Ninurta of Mesopotamia around 1200 BCE. The latter specimens exhibit features that are clearly homologous with elements of the ankh and sema-taui symbols of Ancient Egypt, and share close association of mythic animals that similarly seem to have Nilotic origins.

The ubiquity of this plant symbol and role in religious and ritualistic expression over such a broad geographical range is no less remarkable than the critical role the plant played in modelling the cosmos and defining the concepts of 'first principles' in ancient Egypt and Mesopotamia. The Egyptians identified the world's Creator, Nefertum, as a personification of this sun-like, sweet-smelling plant, and also identified the plant's flowers as the source of the sun itself. Various central members of the Heliopolitan pantheon were symbolized by the plant's continual production of sun-flowers, and were thus equated with the everlasting cycles of life. And by association, successive kings in pharaonic Egypt were equated with these divine personages in life and after death. Like most ancient cosmological concepts, these symbolic and metaphorical notions were communicated by use of various symbols of everlasting life, such as the ankh, sema-taui and shen insignias, all of which migrated and transitioned into closely symbolic forms of the Middle East that assumed the guise of a 'sacral tree,' large scale depictions of which reached a pinnacle of popularity Neo-Assyrian and Neo-Babylonian traditions. The relevance of an Egyptian plant in Mesopotamia owes in no small part to the abundance of this same plant species in marshlands of the Tigris-Euphrates River system. The transition of a herbaceous lotus plant into a sacral tree motif established one of the most pervasive and as yet enigmatic developments in early Middle Eastern iconography which continues to mystify historians and connoisseurs of ancient arts.

Present attempts to identify lotiform tree of life motifs in Mesopotamia with Hebraic concepts of pillared vegetative fetishes known as asherim during Mosaic and post-exilic ages of the Old Testament introduces a number of novel perspectives and underscores ritualistic relations between early Judaic cultures and neighboring tribes. These associations are supported by biblical references to iconography and historical images of libation ceremonies that trace from the Levant and Mesopotamia from 1500-500 BCE, often in association with lotus flowers and lotus-related mythic figures, such as sphinxes and 'cherubim' (chimeras of bulls, eagles, bulls and humans). A review of biblical scriptures emphasizes an under-appreciated role of lotus imagery in the construction and implementation of the temple of Solomon, the holy of holies, and the ark of the covenant, thus broadening our awareness of the influence and religious impacts of Egyptian traditions and rituals among Levantine and Mesopotamian peoples. These novel viewpoints pose new and compelling questions regarding the early developments of religious expression that now seem far removed from our present-day practice of religions that originated in these regions of the world. Perhaps foremost among these questions is the abandoned role of a sacred/mythic plant that formerly played a central role in libation ceremonies, the result of which culminated at times in transcendental experience. 
Funding: This research received no external funding.

Conflicts of Interest: The author declares no conflict of interest.

\section{References}

Albenda, Pauline. 1994. Assyrian sacred trees in the Brooklyn Museum. Iraq 36: 123-33. [CrossRef]

Andrae, Walter. 1925. Coloured Ceramics from Ashur, and Earlier Anci3ent Assyrian Wall Paintings. London: K. Pau, Trench, Tubner \& Co.

Annus, Amar. 2002. The God Ninurta in the Mythology and Royal Ideology of Ancient Mesopotamia. Helsinki: State Archives of Assyria Studies, vol. XVI, pp. 1-242.

Anthes, Rudolph. 1959. Egyptian theology in the third millennium B.C. Journal of Near Eastern Studies 18: 169-212. [CrossRef]

Assaad, Hany, and Daniel Kolos. 1979. The Name of the Dead: Hieroglyphic Inscriptions of the Treasures of Tutankhamun Translated. Mississauga: Benben Publications.

Atac, Mehmet-Ali. 2008. Religion as represented in the art of the ancient Near East. Religion Compass 2: 889-928. [CrossRef]

Babbitt, Frank C. 1936. Moralia: De Iside et Osiride. Plutarch's Moralia V, Loeb Classical Library. Suffolk: St. Edmundsbury Press.

Baines, John. 1975. Ankh sign, belt, and penis sheath. Studien zur altaegyptischen Kulture 3: 1-24.

Barnett, Richad D. 1982. Ancient Ivories in the Middle East. Qedem, Monographs in the Institute of Archaeology. Jerusalem: The Hebrew University.

Barnstone, Willis. 1984. The Other Bible. San Francisco: Harper Collins.

Betz, Hans D. 1986. The Greek Magical Papyri in Translation. Chicago: University of Chicago Press.

Black, Jeremy, Anthony Green, and Tessa Rickards. 1992. Gods, Demons and Symbols of Ancient Mesopotamia. London: British Museum Press.

Bonavia, Emanuel. 1894. The Flora of the Assyrian Monuments. Westminster: Archibald Constable and Co., W.

Brugsch, Heinrich. 1884. Religion und Mythologie der Alten Aegypter. Leipzig: J. C. Hinrichs Publ.

Budge, E. A. Wallis. 1989. Book of the Dead. 2 vols. London: Arkana. First published 1899.

Budge, E. A. Wallis. 1969. The Gods of the Egyptians. 2 vols. New York: Dover. First published 1904.

Budge, E. A. Wallis. 1989. The Mummy, 2nd ed. Cambridge: Constable and Co. First published 1925.

Budge, E. A. Wallis. 1970. Amulets and Talisman. New York: MacMillan. First published 1931.

Cassuto, Umberto. 1971. The Goddess Anath. Jerusalem: Magnes Press.

Chevalier, Jean, and Alain Gheerbrant. 1996. Dictionary of Symbols. Translated by John Buchanan-Brown. London: Penguin.

Cline, E. H. 1995. Egyptian and Near Eastern imports of late Bronze age Mycenae. In Egypt, the Aegean and the Levant. Edited by Vivian Davies and Louise Schofield. London: British Museum Press.

Coomaraswamy, Ananda K. 1935. E. Andrae, Die ionische Säule, Bauform oder Symbol? Art Bulletin 17: 103-7.

Cooper, Jerrold. 2000. Assyrian Prophecies, the Assyrian tree, and the Mesopotamian origins of Jewish monotheism, Greek philosophy, Christian theology, Gnosticism, and much more. Journal of the American Oriental Society 120: 430-44. [CrossRef]

Crowfoot, John W., and Grace M. Crowfoot. 1938. Early Ivories from Samaria. London: Palestine Exporation Fund.

Danthine, Helene. 1937. Le Palmier-Datier et les Arbres Sacre. 2 vols. (text and album). Paris: Librairei Orientaliste Paul Geuthner.

Darby, William J., Paul Ghalioungui, and Louis Grivetti. 1977. Food: The Gift of Osiris. 2 vols. London: Academic Press.

Desroches-Noblecourt, Christiane. 1989. Tutankhamen. New York: Penguin Books.

Durdin-Robertson, Lawrence, and Anna Durdin-Robertson. 1979. The Goddesses of Chaldaea, Syria and Egypt. Enniscorthy: Cesara Publ.

El-Mallakh, Kamal, and Robert S. Bianchi. 1980. Treasures of the Nile: Art of the Temples and Tombs of Egypt. Tokyo: Newsweek Inc. and Kodansha Ltd.

Emboden, William. 1979. Nymphaea ampla and other narcotics in Maya drug ritual and religion. Mexicon 1: 50-52.

Emboden, William. 1981. Transcultural use of narcotic water lilies in ancient Egyptian and Mayan drug ritual. Journal of Ethnopharmacology 3: 39-83. [CrossRef]

Emboden, William. 1989a. The sacred narcotic lily of the Nile: Nymphaea caerulea. Economic Botany 32: $395-407$. [CrossRef] 
Emboden, William. 1989b. The sacred journey in dynastic Egypt: Shamanistic trance in the context of the narcotic water lily and the mandrake. Journal of Psychoactive Drugs 21: 61-75. [CrossRef] [PubMed]

Faulkner, Raymond O. 1969. The Ancient Egyptian Pyramid Texts. Oxford: Clarendon Press.

Faulkner, Raymond O. 2004. Ancient Egyptian Coffin Texts. Oxford: Aris and Phillips.

Fox, Penelope. 1951. Tutankhamun's Treasure. London: Oxford University Press.

Frankfort, Henri. 1939. Cylinder Seals. London: Macmillan and Co.

Frankfort, Henri. 1970. The Art and Architecture of the Ancient Orient. London: Penguin Group.

Gardiner, Alan H. 1928. Life and death. In Encyclopaedia of Religion and Ethics. Edited by James Hastings. New York: Charles Scribner's Sons, vol. 8.

Gardiner, Alan H. 1950. Egyptian Grammar, 2nd ed. London: Oxford University Press.

Garlick, Constance. 1918. Notes on the Sacred Tree in Mesopotamia. Proceedings of the Society of Biblical Archaeology 40: 111-12.

Gillispie, Charles C., and Michel Dewachter. 1987. The Monuments of Egypt: The Napoleonic Edition. Old Saybrook: Konecky and Konecky.

Giovino, Mariana. 2007. The Assyrian Sacred Tree: A History of Interpretations. Orbis Biblicus et Orientalis 230. Göttingen: Vandenhoeck and Ruprecht.

Goodyear, William H. 1887. Egyptian origin of the ionic capital and the anthemion. The American Journal of Archaeology and of the History of Fine Arts 3: 271-302. [CrossRef]

Goodyear, William H. 1891. The Grammar of the Lotus. London: Sampson Low, Marston and Co.

Gordon, Andrew H., and Calvin W. Schwabe. 2004. The Quick and the Dead: Biomedical Theory in Ancient Egypt. Leiden: E. J. Brill.

James, Edwin O. 1966. The Tree of Life. Leiden: E. J. Brill.

Jones, Owens. 1995. The Grammar of Ornament. London: Bernard Quaritch. First Published 1856.

Keel, Othmar, and Christoph Uehlinger. 1998. Gods, Goddesses, and Images of God in Ancient Israel. Translated by Thomas Trapp. Minneapolis: Fortress Press.

Kramer, Samuel N. 1974. Kingship in Sumer and Akkad: The ideal king. In Le Palais et la Royauté: archéologie et Civilization. Edited by Paul Garelli. Paris: Geuthner, pp. 163-76.

Lang, Bernhard. 1983. Monotheism and the Prophetic Minority. Sheffield and Decatur: Almond Press.

Langdon, Stephen. 1914. Tammuz and Ishtar. Oxford: Clarendon Press.

Langdon, Stephen. 1928. The legend of the kiskanu. Transactions of the Royal Asian Society, Great Britain and Ireland 1: 843-48. [CrossRef]

Lange, Kurt, and Max Hirmer. 1968. Egypt: Architecture, Sculpture, Painting in Three Thousand Years, 4th ed. London: Phaidon Press.

Layard, Austen Henry. 1849. Nineveh and its Remains: with an Account of a Visit to the Chaldaean Christians of Kurdistan, and the Yezids, or Devil-Worshippers; and an Enquiry in the Manners and Arts of the Ancient Assyrians. 2 vols. London: John Murray.

Loud, Gordon. 1939. The Megiddo Ivories. Chicago: University of Chicago Press.

Lurker, Manfred. 1980. The Gods and Symbols of Ancient Egypt. London: Thames and Hudson.

Maspero, Gaston. 1913. Egyptian Art. London: T. Fisher Unwin.

Mazar, Benjamin. 1961. Views of the Biblical World. 5 vols. Jerusalem: International Publishing.

McDonald, J. Andrew. 2002. Botanical determination of the Middle Eastern tree of life. Economic Botany 56: 113-29. [CrossRef]

McDonald, J. Andrew, and Brian Stross. 2012. Water lily and cosmic serpent: Equivalent conduits of the Maya spirit realm. Journal of Ethnobiology 32: 73-106. [CrossRef]

Merhav, Rivka. 1987. Treasures of the Bible Lands. Tel Aviv Museum. Tel Aviv: Modan Publishing.

Moldenke, Harold, and Alma Moldenke. 1952. Plants of the Bible. New York: Ronald Press.

Parpola, Simo. 1993. The Assyrian tree of life: Tracing the origins of Jewish monotheism and Greek philosophy. Journal of Near Eastern Studies 52: 161-208. [CrossRef]

Parpola, Simo. 1997. Assyrian Prophecies. State Archives of Assyria. Helsinki: Helsinki University Press, vol. 9.

Parrot, Andre. 1961. The Arts of Assyria. New York: Golden Press.

Patai, Raphael. 1990. The Hebrew Goddess, 3rd ed. Detroit: Wayne State University Press.

Piankoff, Alexandre. 1964. The Litany of Re. New York: Pantheon Books.

Piankoff, Alexandre. 1968. The Pyramid of Unas. Princeton: Princeton University Press. 
Piankoff, Alexandre. 1974. The Wandering of the Soul. Princeton: Princeton University Press.

Porada, Edith. 1945. Griffin demons, genii and griffin demons. In The Great King of Assyria: Assyrian Reliefs in the Metropolitan Museum of Art. Edited by Charles Sheeler. New York: Metropolitan Museum of Art.

Porter, Barbara N. 1993. Sacred trees, date palms, and the royal persona of Ashurnasirpal II. Journal of Near Eastern Studies 52: 129-39. [CrossRef]

Pritchard, James B. 1969. Ancient Near Eastern Texts Relating to the Old Testament, 3rd ed. Princeton: University Press. Redford, Donald B. 1992. Egypt, Canaan, and Israel in Ancient Times. Princeton: Princeton University Press.

Roaf, Michael. 1998. Cultural Atlas of Mesopotamia and the Near East. Oxfordshire: Andromeda.

Schäfer, Heinrich. 1974. Principles of Egyptian Art. Translated by Emma Brunner-Traut. Oxford: Clarendon.

Schneider, Edward L. 1982. Notes on the floral biology of Nymphaea elegans (Nymphaeaceae) in Texas. Aquatic Botany 12: 197-200. [CrossRef]

Schweinfurth, Georg. 1884. The Flora of Ancient Egypt. Nature 28: 109-14.

Shaw, Ian, and Paul Nicholson. 1995. The Dictionary of Ancient Egypt. New York: British Museum, Harry N. Abrams Inc.

Strommenger, Eva. 1964. 5000 Years of the Art of Mesopotamia. Translated by Christina Haglund. New York: H. N. Abrams. Walker, Winifred. 1957. All the Plants of the Bible. New York: Harper and Brothers.

Ward, William H. 1910. The Seal cylinders of Western Asia. Carnegie Institution of Washington, Publication no. 100. Washington, DC: Carnegie Institution.

Wiersema, John H. 1988. Reproductive biology of Nymphaea (Nymphaeaceae). Annals of the Missouri Botanical Garden 73: 795-804. [CrossRef]

Wiggins, Steve A. 1993. A Reassessment of 'Asherah. Darmstadt: Verlag Butzon and Bercker Kevelaer. Wilkinson, Richard H. 1992. Reading Egyptian Art. New York: Thames and Hudson.

Wilkinson, Richard H. 1994. Symbol and Magic in Egyptian Art. New York: Thames and Hudson.

Wilkinson, Richard H. 2003. The Complete Gods and Goddesses of Ancient Egypt. New York: Thames and Hudson.

(C) 2018 by the author. Licensee MDPI, Basel, Switzerland. This article is an open access article distributed under the terms and conditions of the Creative Commons Attribution (CC BY) license (http://creativecommons.org/licenses/by/4.0/). 